\title{
The biochemistry of diabetes
}

\author{
Roy TAYLOR and Loranne AGIUS \\ Department of Medicine, University of Newcastle upon Tyne, Framlington Place, Newcastle upon Tyne NE2 4HH, U.K.
}

\section{INTRODUCTION}

We have attempted to review this broad subject not by being comprehensive, but rather by emphasizing areas of recent advance.

The hallmark of diabetes mellitus is an inability to control blood glucose. There are two major clinical syndromes: one characterized by insulin dependence and early age of onset with weight loss and ketonuria, and the second characterized by relatively later onset, insensitivity to insulin and partial insulin deficiency. Dearth of precise knowledge about pathogenesis makes aetiological classification hazardous, and in this review the descriptive terms insulin-dependent diabetes (IDDM) and noninsulin dependent diabetes (NIDDM) will be used.

\section{METABOLIC DISTURBANCE IN MAN}

\section{Carbohydrate metabolism}

Fasting state. In normal subjects, fasting blood glucose is maintained constant by control of hepatic glucose output. After an overnight fast, approx. $75 \%$ of hepatic glucose output is accounted for by glycogenolysis and the rest by gluconeogenesis from lactate, alanine, glycerol, and pyruvate in decreasing order of importance (Hers \& Hue, 1983). Hepatic glucose output is controlled by basal levels of insulin and glucagon. Basal hepatic extraction of insulin and glucagon is approx. $50 \%$ (Waldhausl et al., 1982); and hence insulin and glucagon concentrations in the peripheral circulation are lower than in the portal vein. At least $70 \%$ of extrahepatic glucose utilization occurs in insulin-insensitive tissues (brain, red blood cells and renal medulla) (Vranic \& Wrenshall, 1968).

In NIDDM, fasting blood glucose is raised in direct proportion to hepatic glucose output (Bogardus et al., 1984; Revers et al., 1984; DeFronzo et al., 1985), and appears unlikely to be a result of decreased insulin action at the periphery as it has not been shown to correlate closely with insulin-stimulated glucose disposal (Bogardus et al., 1984; DeFronzo et al., 1982a). As fasting plasma insulin and C-peptide concentrations are normal in NIDDM, the elevated hepatic glucose output is likely to reflect a degree of hepatic insulin insensitivity. Study of the insulin dose-response of suppression of hepatic glucose output supports this concept (Revers et al., 1984).

Postprandial state. In normal subjects, first-pass hepatic glucose extraction is low and over $90 \%$ of an oral glucose load reaches the peripheral circulation (Radziuk et al., 1978; Pehling et al., 1984). Over the subsequent few hours approximately one-third of glucose is cleared by the liver (Katz et al., 1983). Uncertainty persists about the proportion of glucose stored by the liver which is derived from 3-carbon precursors formed in the periphery, but this is currently thought to be considerable (Katz \& McGarry, 1984). The post-meal hyperinsulinaemia inhibits lipolysis and stimulates storage of glucose and fatty acids as glycogen in muscle and liver and as triacylglycerol in adipose tissue.

In NIDDM subjects, study of plasma insulin levels throughout the day has demonstrated that, although the incremental responses to meals are decreased and delayed, the prolonged postprandial peaks ensure that mean diurnal plasma insulin levels are elevated (Liu et al., 1983). Postprandial rates of gluconeogenesis are not suppressed (Wahren et al., 1972; Hall et al., 1979) and total hepatic glucose release as assessed isotopically is excessive (Firth et al., 1986a). Gluconeogenesis from meal-derived 3-carbon precursors is somewhat greater in NIDDM than in normal subjects.

Following glucose ingestion, splanchnic lactate uptake changes to net output and forearm oxygen uptake and lactate balance do not change (Meistas et al., 1985; Jackson et al., 1986). These findings suggest that intestine or liver metabolizes glucose to lactate, some of which is eventually stored by the liver as glycogen and fatty acid. Most of the glucose taken up by muscle must therefore be stored. Jackson et al. (1987b) demonstrated a transient period of lactate uptake in forearm muscle after glucose loading (probably a mass action effect related to hyperlactataemia) and showed that there was no marked decrease in skin lactate output over the same period. Fasting superficial venous lactate concentrations are greater than either arterial or deep venous concentrations, and therefore skin must be one of the major organs of lactate production (Jackson et al., 1987b).

Although the insulin-mediated increment in muscle glucose uptake is subnormal in NIDDM, absolute postprandial rates of glucose uptake are normal when measured directly by the forearm technique at prevailing blood glucose concentrations despite the marked insulin insensitivity (Jackson et al., 1973; Firth et al., 1986a). This reflects the mass action effect of glucose on tissue uptake (Revers et al., 1984).

Relatively few studies on human muscle enzymes have been carried out. Falholt et al. (1987) found decreased fasting activity of hexokinase and phosphofructokinase, suggesting a potential decrease in glycolysis in NIDDM subjects, but glucose-6-phosphate dehydrogenase and malic enzyme activities were elevated and so was muscle triacylglycerol. However, the patients studied were remarkably hyperinsulinaemic, fasting plasma insulin levels being 6-fold elevated, and thus not representative of the majority of NIDDM subjects.

Abbreviations used: IDDM, insulin-dependent diabetes mellitus; NIDDM, non-insulin-dependent diabetes mellitus; VLDL, very-low-density lipoprotein; GH, growth hormone; IGF, insulin-like growth factor; NEFA, non-esterified fatty acids.

Vol. 250 
Table 1. Mean diurnal plasma concentrations of intermediary metabolites under differing degrees of glycaemic control and insulinaemia

Data represent $12 \mathrm{~h}$ day-time means, ${ }^{*} 24 \mathrm{~h}$ means, or $\dagger 4 \mathrm{~h}$ means, compared with normal subjects. SU, sulphonylurea; SC, subcutaneous insulin; N, normal; $\uparrow$, significantly raised; $\downarrow$, significantly low.

\begin{tabular}{|c|c|c|c|c|c|c|c|c|c|}
\hline $\begin{array}{l}\text { Subjects } \\
\text { and } \\
\text { therapy }\end{array}$ & Lactate & Pyruvate & Alanine & Glycerol & NEFA & $\begin{array}{c}\text { 3-Hydroxy- } \\
\text { butyrate }\end{array}$ & $\begin{array}{l}\text { Glucose } \\
(\mathrm{mmol} / \mathrm{l})(\end{array}$ & $\begin{array}{c}\text { Insulin } \\
\text { (m-units/l) }\end{array}$ & Reference \\
\hline \multicolumn{10}{|l|}{ NIDDM } \\
\hline Diet & $\mathbf{N}$ & $\uparrow$ & $\uparrow$ & $\downarrow$ & - & $\mathbf{N}$ & 7.0 & 16 & Nattrass (1982) \\
\hline Diet & $\mathbf{N}$ & $\mathbf{N}$ & $\mathbf{N}$ & $\mathbf{N}$ & - & $\mathbf{N}$ & 7.9 & - & †Sheppard et al. (1983) \\
\hline Diet & $\uparrow$ & $\uparrow$ & $\uparrow$ & $\uparrow$ & $\mathbf{N}$ & $\uparrow$ & 11.8 & 23 & †Samad et al. (1987) \\
\hline Diet & - & - & - & - & $\uparrow$ & $\uparrow$ & 18.4 & 7 & Nankervis et al. (1982) \\
\hline Diet & - & - & - & - & $\uparrow$ & - & 12.2 & 33 & †Fraze et al. (1985) \\
\hline Nil & $\uparrow$ & $\uparrow$ & $\uparrow$ & $\mathbf{N}$ & - & $\uparrow$ & 13.2 & - & †Sheppard et al. (1983) \\
\hline SU & $\uparrow$ & $\uparrow$ & $\uparrow$ & $\downarrow$ & $\downarrow$ & $\mathbf{N}$ & 11.4 & - & †I. R. Jones (unpublished work) \\
\hline SU & $\mathbf{N}$ & $\mathbf{N}$ & $\mathbf{N}$ & $\downarrow$ & $\mathbf{N}$ & $\mathbf{N}$ & 5.2 & 20 & Nattrass et al. (1978) \\
\hline SU & $\uparrow$ & $\uparrow$ & $\uparrow$ & $\uparrow$ & - & $\mathbf{N}$ & 13.2 & 26 & Nattrass (1982) \\
\hline Metformin & $\uparrow$ & $\uparrow$ & $\uparrow$ & $\downarrow$ & $\mathbf{N}$ & $\mathbf{N}$ & 7.0 & 19 & Nattrass et al. (1977) \\
\hline \multicolumn{10}{|l|}{ IDDM } \\
\hline SC & $\mathbf{N}$ & - & $\mathbf{N}$ & $\uparrow$ & - & $\uparrow$ & 12.9 & 29 & Madsbad et al. (1981) \\
\hline $\mathrm{SC}$ & $\uparrow$ & $\uparrow$ & $\mathbf{N}$ & $\mathbf{N}$ & - & $\uparrow$ & 12.1 & 31 & *Capaldo et al. (1984) \\
\hline SC & $\mathbf{N}$ & $\mathbf{N}$ & $\downarrow$ & $\mathbf{N}$ & - & $\uparrow$ & 8.5 & 16 & *Marshall et al. (1987) \\
\hline SC & $\uparrow$ & $\uparrow$ & $\mathbf{N}$ & $\downarrow$ & $\mathbf{N}$ & $\mathbf{N}$ & 8.3 & 52 & Nosadini et al. (1982) \\
\hline Biostator & $\uparrow$ & $\uparrow$ & $\mathbf{N}$ & $\downarrow$ & $\mathbf{N}$ & $\mathbf{N}$ & 5.6 & 81 & Nosadini et al. (1982) \\
\hline
\end{tabular}

In subjects with IDDM, postprandial hyperglycaemia is the consequence of the lack of an appropriate sharp increase in circulating insulin levels, and reflects inadequacies in the dynamics of insulin delivery. Hepatic release of glucose is relatively uninhibited and this, together with the demonstrated resistance to insulin in peripheral tissues (Proietto et al., 1983; Yki-Jarvinen et al., 1984), results in postprandial hyperglycaemia. The results of studies on circulating concentrations of intermediary metabolites are summarized in Table 1. A striking feature is the high lactate in IDDM and poorly controlled NIDDM. Strong correlations have been reported between mean $24 \mathrm{~h}$ plasma insulin and lactate concentrations (Capaldo et al., 1984; Alberti et al., 1975). The high lactate persists during establishment of normoglycaemia over a $24 \mathrm{~h}$ period, although in this situation measured Cori cycle activity is suppressed (Nosadini et al., 1982). It is possible that the hyperlactataemia may represent an imbalance of insulin action on peripheral tissues compared with liver, as subcutaneous or intravenous insulin administration leads to equal levels of insulin in the peripheral circulation and portal vein, unlike the normal situation. Restoration of the portal-peripheral insulin gradient returns lactate concentrations towards normal (Jimenez et al., 1985; Stevenson et al., 1983). In poorly controlled NIDDM subjects, the portal-peripheral insulin gradient is preserved, but it is possible that peripheral tissues become relatively more resistant to insulin action (see below). Proinsulin appears to have a slightly greater effect on the liver than on peripheral tissues in vivo and the rise in plasma lactate usually associated with insulin infusion is not seen when doses of proinsulin are infused to produce similar increments in overall glucose disposal (Davis et al. 1986). Changes in circulating pyruvate and alanine tend to reflect lactate concentrations and hence degree of metabolic control and hyperinsulinaemia (Table 1).

\section{The sorbitol (polyol) pathway}

One of the consequences of hyperglycaemia in human diabetes mellitus is increased metabolism of glucose by the sorbitol pathway. This involves the reduction of glucose to sorbitol catalysed by aldose reductase (EC 1.1.1.21) and the oxidation of sorbitol to fructose by sorbitol dehydrogenase (EC 1.1.1.14). Aldose reductase is present in human brain, nerves, aorta, muscle, erythrocytes and ocular lens (Srivastava et al., 1984; Das \& Srivastava, 1985b). Although the purified enzyme has a low affinity for glucose $\left(K_{\mathrm{m}}\right.$ approx. $\left.100 \mathrm{~mm}\right)$ (Moonsammy \& Stewart, 1967), it can be activated by glucose 6-phosphate, NADPH and glucose (Das \& Srivastava, $1985 a, b)$. Sorbitol is not permeable to cell membranes and tends to accumulate in the cell. At high [glucose] the flux through the sorbitol pathway in rabbit lens may account for one-third of glucose metabolism (Gonzalez et al., 1984). This has important implications in terms of redox changes of NADP and NAD couples and metabolism of glucose by alternative pathways (Jeffrey \& Jornvall, 1983).

Conversion of glucose to sorbitol by aldose reductase requires NADPH and forms $\mathrm{NADP}^{+}$(Fig. 1) and thereby competes with other NADPH-requiring reactions. NADPH is required for the conversion of oxidized to reduced glutathione, a powerful antioxidant which protects cellular components from oxidative damage, and for fatty acid and cholesterol biosynthesis. The pentose phosphate pathway is the major source of NADPH in most tissues and its flux is generally determined by the $\mathrm{NADP}^{+} / \mathrm{NADPH}$ ratio. Conversion of sorbitol to fructose is coupled to reduction of NAD N $^{+}$ to NADH and this competes with glycolysis at the glyceraldehyde dehydrogenase step for $\mathrm{NAD}^{+}($Gonzalez et al., 1986). An increase in the $\mathrm{NADH} / \mathrm{NAD}^{+}$ratio favours increased conversion of dihydroxyacetone 


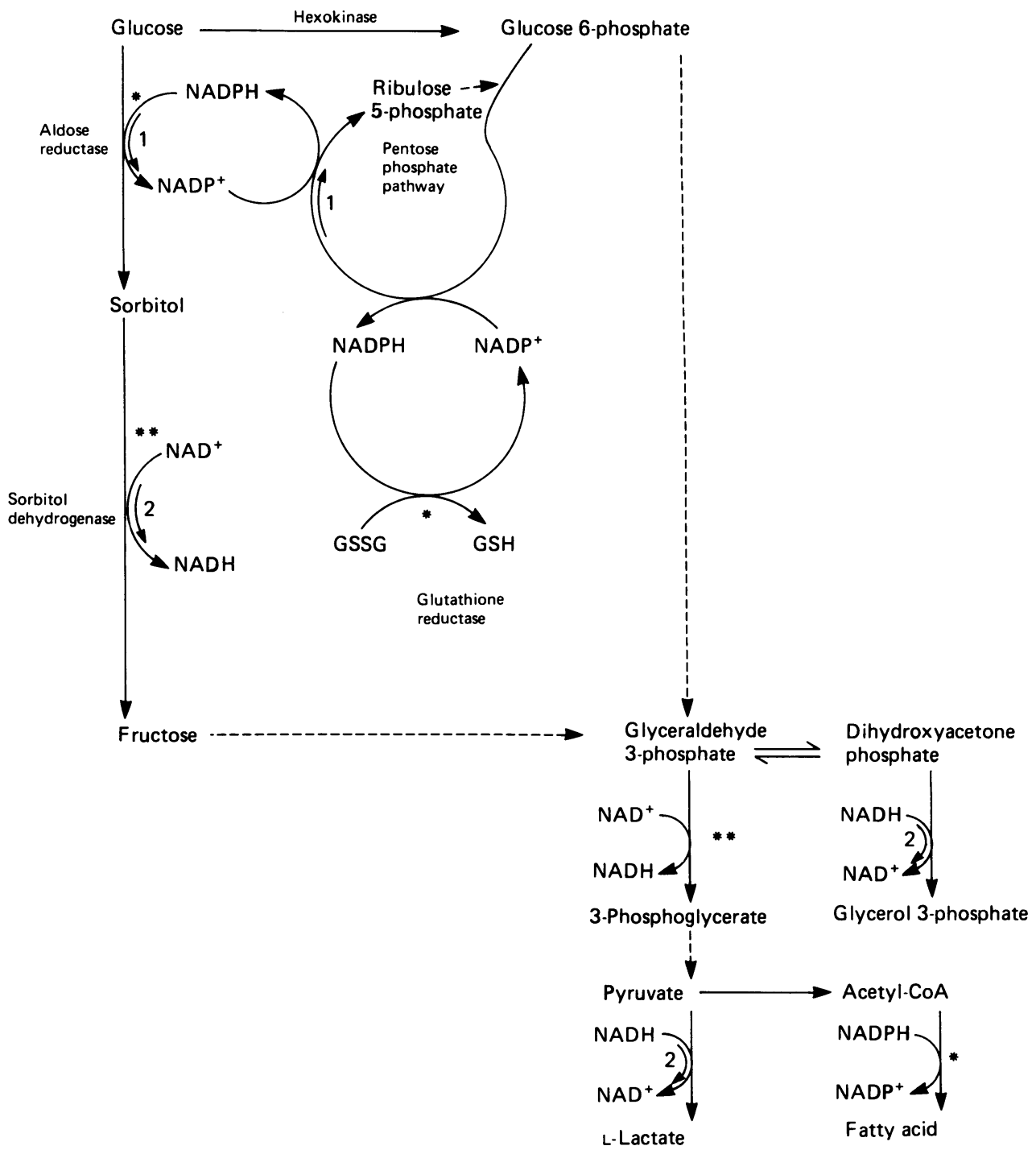

Fig. 1. The sorbitol pathway and its links with the pentose phosphate pathway and glycolysis through the $\mathrm{NADP}^{+}$and $\mathrm{NAD}^{+}$redox couples

The sorbitol pathway involves: conversion of glucose to sorbitol by aldose reductase and sorbitol to fructose by sorbitol dehydrogenase. Reactions coupled to oxidation of NADPH are indicated by ${ }^{*}$ and reactions coupled to reduction of NAD ${ }^{+}$are indicated by **. Aldose reductase competes with glutathione reductase for NADPH and sorbitol dehydrogenase competes with glyceraldehyde-3-phosphate dehydrogenase for NAD ${ }^{+}$. (1) An increased flux through aldose reductase favours an increased activity of the pentose phosphate pathway (Gonzales et al., 1986) and increased flux through sorbitol dehydrogenase favours increased conversion of dihydroxyacetone phosphate to glycerol 3-phosphate (Gonzalez et al., 1983) and decreased conversion of glyceraldehyde 3-phosphate to 3-phosphoglycerate.

phosphate to glycerol 3-phosphate. In rat lens, increased flux through aldose reductase is associated with increased pentose phosphate pathway activity, decreased glycolysis (Gonzalez et al., 1986), accumulation of glycerol 3-phosphate and depletion of reduced glutathione (Whikehart \& Soppet, 1981; Gonzalez et al., 1984).

\section{Disturbances in lipid metabolism}

Fatty acid mobilization and production and utilization of ketone bodies. One of the most prominent features of insulin deficiency is rapid mobilization of fatty acids from adipose tissue. In IDDM, excessive lipolysis during insulin deficiency is the combined result of insulin lack and insulin resistance (Singh et al., 1987). One of the consequences of excessive mobilization of fatty acids in
IDDM is the production of ketone bodies (acetoacetate, 3-hydroxybutyrate and acetone) in liver. Fatty acids taken up by the liver, after conversion to their CoA esters, are either esterified to glycerolipid or oxidized to acetyl-CoA in mitochondria. A high proportion of the acetyl-CoA formed is converted to acetoacetate and 3-hydroxybutyrate. The rate of transfer of fatty acyl units to the mitochondria is regulated by the activity of carnitine palmitoyltransferase I (EC 2.3.1.21), which faces the intermitochondrial membrane space and catalyses the first step specific to mitochondrial fatty acid oxidation. Carnitine palmitoyltransferase $I$ is regulated by malonyl-CoA, an intermediate in fatty acid synthesis, and it is also regulated by a phosphorylation mechanism. Malonyl-CoA decreases the affinity of the enzyme for its 


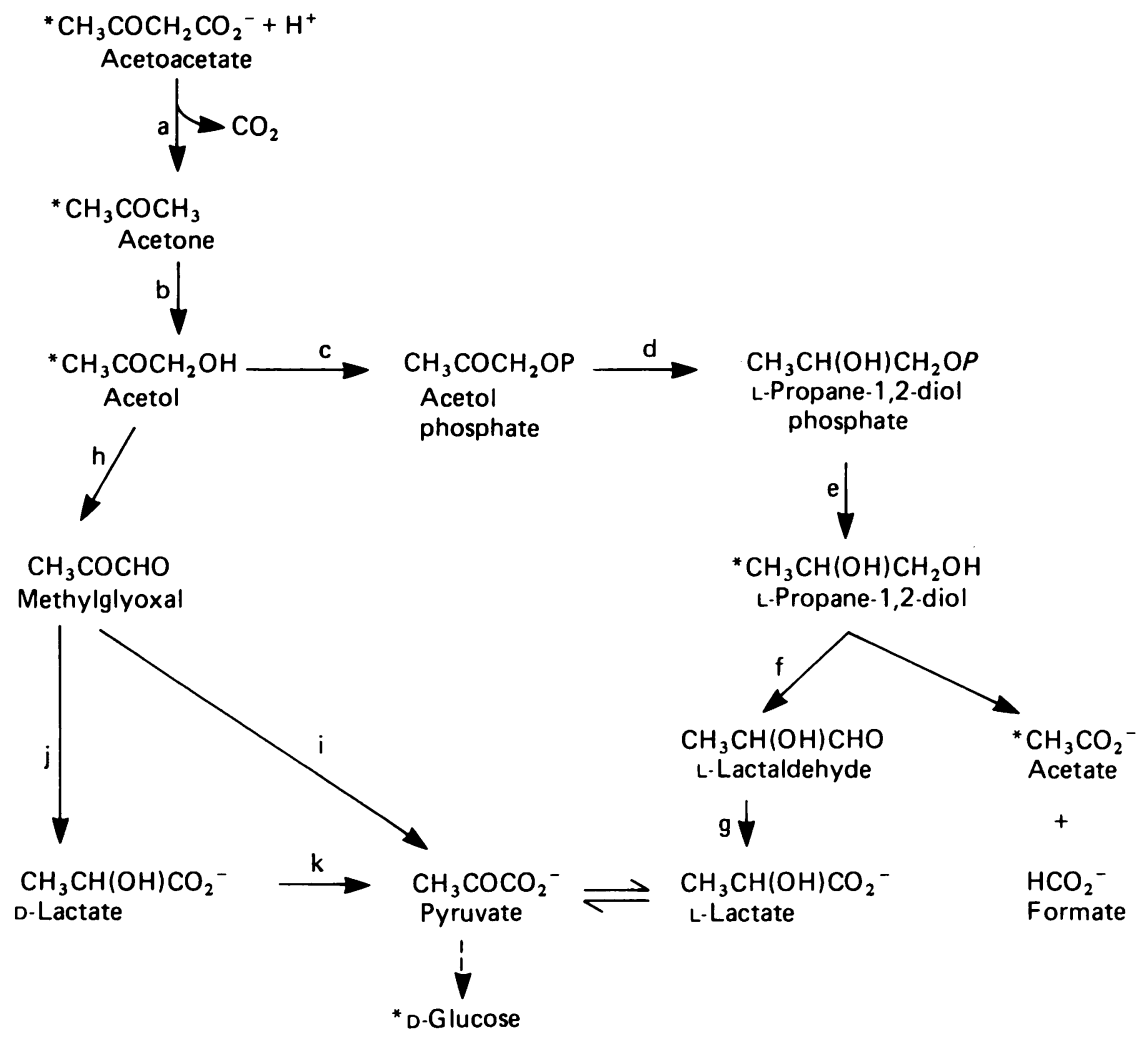

Fig. 2. Postulated pathways for the metabolism of acetone to glucose and acetate

Intermediates marked by * increase in human plasma during ketosis (Reichard et al., 1986). Enzymes: a, acetoacetate decarboxylase; $b$, acetone mono-oxygenase $\left(\mathrm{NADP}^{+}\right) ; \mathrm{c}$, acetol kinase; d, propanediol phosphate dehydrogenase $\left(\mathrm{NADP}^{+}\right)$; $\mathrm{e}$ phosphatase; f, lactaldehyde reductase $\left[\mathrm{NAD}(\mathrm{P})^{+}\right]$; g, lactaldehyde dehydrogenase $\left(\mathrm{NAD}^{+}\right)$; h, acetol mono-oxygenase $\left(\mathrm{NADP}^{+}\right)$; i, 2-oxoaldehyde dehydrogenase [NAD $\left.(\mathrm{P})^{+}\right]$; j, glyoxylase I and II; k, D-2-hydroxyacid dehydrogenase (FAD); l, lactate dehydrogenase $\left(\mathrm{NAD}^{+}\right)$.

fatty acyl-CoA substrate (McGarry et al., 1977), while phosphorylation increases the affinity for substrate (Harano et al., 1985). In insulin deficiency, the rate of fatty acid synthesis in liver declines and consequently the concentration of malonyl-CoA also decreases, and the affinity of carnitine palmitoyltransferase for malonylCoA also decreases (Gamble \& Cook, 1985), thus relieving the inhibition of carnitine palmitoyltransferase by malonyl-CoA. Changes in the kinetic properties of detergent-solubilized carnitine palmitoyltransferase following exposure of liver cells to glucagon (activation) or insulin (inactivation) have also been observed (Harano et al., 1985; Agius et al., 1986b), indicating that additional mechanisms contribute to activation (or deinhibition) of carnitine palmitoyltransferase in insulin deficiency, thereby favouring increased transfer of long-chain fatty acids into mitochondria.

The utilization of acetoacetate and 3-hydroxybutyrate as oxidative fuels (or lipogenic substrates) by a variety of tissues is well established (Robinson \& Williamson, 1980) and increases with blood ketone body concentration in the fed-to-fasted transition (Miles et al., 1980). In muscle, at ketone body concentrations attained in prolonged starvation or diabetic ketosis, the rate of uptake reaches saturation (Owen \& Reichard, 1971). Consequently, with increasing ketone body production and thereby plasma concentration, there is a progressive decrease in total fractional clearance (Fery \& Balasse, 1985).
Although the biochemical routes of metabolism of acetoacetate and 3-hydroxybutyrate are well established, the conversion of acetoacetate to acetone and its subsequent excretion or metabolism has only recently received attention. In man, plasma [acetone] correlates with, and is generally higher than, [acetoacetate] in fasting and diabetic ketosis (Owen et al., 1982) and the production rate is estimated to be about half the rate of ketogenesis (Reichard et al., 1986). Conversion of acetoacetate to acetone can occur either non-enzymically or catalysed by acetoacetate decarboxylase (EC 4.1.1.4) (Argiles, 1986). The occurrence of this enzyme has been demonstrated in various rat tissues, but only in human plasma (Koorevaar \& van Stekelenburg, 1976). The high acetone production rate in man suggests the occurrence of the enzyme in other tissues. At low plasma acetone concentrations (1-2 mM), as occur in fasting ketosis, about $20 \%$ is excreted (in breath and urine) and the rest metabolized, whereas at higher concentrations, as in diabetic ketosis (7-9 mM), about $80 \%$ is excreted (Owen et al., 1982). In the rat, acetone is hydroxylated to acetol which is either converted to methylglyoxal or to propane1,2-diol (Fig. 2). The former is converted to pyruvate either directly or indirectly (Cassava et al., 1984), whereas propane-1,2-diol is either oxidized to L-lactate or converted to acetate and formate (Kosugi et al., 1986a,b) (Fig. 2). Studies on the incorporation of $\left[2-{ }^{14} \mathrm{C}\right]$ acetone into glucose in the rat have shown that at low plasma [acetone] it is metabolized primarily to lactate and 
pyruvate, but at high plasma [acetone], acetate formation predominates (Kosugi et al., 1986b). Recent evidence suggests that in human diabetic ketosis acetone metabolism may be very similar (Reichard et al., 1986). [2-14 C]Acetone was incorporated into glucose via pyruvate and lactate in the majority of patients, but, in one subject with high plasma [acetone], label incorporation was predominantly via acetate formation (Reichard et al., 1986). These findings suggest that, in moderate ketosis in man, acetone is a potential gluconeogenic substrate.

Triacylglycerol secretion and clearance. The plasma triacylglycerol concentration is elevated in both IDDM and NIDDM (Nikkila, 1984). In IDDM, decreased clearance seems to be the main cause of the high triacylglycerol level (Bagdade et al., 1968; Nikkila et al., 1977; Taskinen \& Nikkila, 1979), whereas in NIDDM the triacylglycerolaemia may be due to increased production by the liver (Greenfield et al., 1980; Kissebah et al., 1982; Dunn et al., 1984) and decreased clearance (Nikkila et al., 1977; Taskinen et al., 1982; Pfeifer et al., 1983). Production of triacylglycerol by the liver involves the esterification of fatty acid, either synthesized de novo in the liver from dietary carbohydrate and amino acid, or derived from adipose tissue reserves. The triacylglycerol is either stored intracellularly or it is packaged with apoproteins and secreted in the form of VLDL. Under certain conditions fatty acid esterification increases with increasing fatty acid concentration and appears to be non-saturable (Ontko, 1972). VLDL secretion, in contrast, may be limited by the availability of aproproteins or other components of the lipoprotein particle. When VLDL secretion reaches saturation, triacylglycerol accumulates inside the liver. The elevated plasma triacylglycerol in diabetes is generally associated with VLDL, although increases in other lipoproteins (LDL and HDL) also occur (Gibbons, 1986).

In absolute insulin deficiency, the plasma concentration and turnover of fatty acids increases, whereas fatty acid synthesis de novo decreases and the proportion of fatty acyl-CoA that is esterified as opposed to oxidized also decreases. Any absolute increase in hepatic fatty acid esterification depends on whether the increase in fatty acid availability compensates for the increased fractional diversion towards mitochondrial oxidation. In patients with IDDM, intensive insulin therapy, which is associated with a higher mean plasma insulin compared with conventional insulin therapy, results in a decrease in triacylglycerol secretion rate (Dunn et al., 1987, Pietri et al., 1983). Whether the effect of the increased insulinization was primarily due to a decrease in fatty acid availability or to inhibition of VLDL secretion is not clear.

Triacylglycerol secretion rates are generally higher in NIDDM than in IDDM (Greenfield et al., 1980). In normolipaemic NIDDM, triacylglycerol secretion and clearance are both increased, whereas in hyperlipaemic NIDDM, fractional turnover rate is reduced such that increased triacylglycerol removal does not compensate for the increase in secretion rate (Kissebah et al., 1982). In NIDDM with decreased VLDL clearance, the composition of VLDL is abnormal, with a high triacylglycerol/apoprotein B ratio (Taskinen et al., 1986), indicating multiple abnormalities in VLDL metabolism. A key issue is whether changes in adipose tissue lipolysis, or intrahepatic mechanisms involving either changes in fractional esterification of fatty acid or in the assembly and secretion of VLDL, are responsible for the increase in triacylglycerol secretion rate in NIDDM. Studies in vitro on the effects of insulin on fatty acid esterification and secretion of VLDL have led to conflicting hypotheses. In the perfused rat liver, insulin acutely increases triacylglycerol secretion (Topping \& Mayes, 1982; Laker $\&$ Mayes, 1984), but in rat hepatocyte cultures incubated under conditions of high rates of fatty acid synthesis de novo, insulin decreases the rate of triacylglycerol secretion during a 16-18 h incubation (Durrington et al., 1982; Patsch et al., 1983, 1986). On the basis of the former studies, elevated triacylglycerol secretion rates in NIDDM are suggested to be due to hyperinsulinization of the liver, increasing esterification and VLDL secretion, whereas on the basis of the latter studies it might be argued that hepatic insulin resistance may be responsible for the lack of insulin inhibition of triacylglycerol secretion. The lack of understanding of the physiological effects of insulin on hepatic fatty acid esterification and VLDL secretion renders the interpretation of the lesions in diabetes very difficult.

\section{HORMONE ACTIONS IN MAN}

\section{Insulin}

Mechanism of insulin action. The extent to which primary or secondary defects in insulin receptor activity can explain cellular insensitivity to insulin is still hotly debated. The insulin receptor is well characterized (Kahn, 1985) and its gene has been cloned (Ullrich et al., 1985). It comprises two $135 \mathrm{kDa} \alpha$ subunits which are extracellular and contain insulin-binding sites, and are linked by disulphide bonds to two $95 \mathrm{kDa} \beta$ subunits. The $\beta$ subunit has a hydrophobic transmembrane region, and an intracellular domain which has several tyrosine residues, a tyrosine kinase and an ATP-binding site. Insulin binding to the $\alpha$ subunits activates the $\beta$ subunit tyrosine protein kinase and brings about phosphorylation of tyrosine residues on the $\beta$ subunit. Activation of the $\beta$ subunit kinase may be involved in transmission of the insulin signal, perhaps by initiating a phosphorylation/ dephosphorylation cascade (Denton et al., 1981). Kinase activity of the insulin receptor can be decreased by cyclic AMP-dependent protein kinase phosphorylation of serine or threonine sites on the $\beta$ subunit, and this could conceivably underlie catecholamine-induced insulin resistance (Roth \& Beaudoin, 1987). In states of extreme insulin resistance (Grigorescu et al., 1987; Grunberger et al., 1984; Le Marchand-Brustel et al., 1985) and NIDDM (Freidenberg et al., 1987; Caro et al., 1986) the process of signal transmission from the receptor $\alpha$ subunit insulin-binding site to activate the kinase appears to be defective at one or more sites. Amino acid substitution in the ATP-binding region or the tyrosine kinase region (Chou et al., 1986; Ellis et al., 1986) abolishes insulin action. Whether or not the kinase is involved in mediating all actions of insulin remains uncertain. Some antireceptor antibodies simulate insulin action without changing kinase activity (Simpson \& Hedo, 1984; Forsayeth et al., 1987). Not all actions of insulin are modulated in parallel by treatment of insulinresistant states, suggesting that divergent pathways of intracellular insulin signal transmission may be separately affected (Boden et al., 1983; Pedersen \& Hjollund, 1982). A remarkable array of second messengers of insulin 
action (Saltiel et al., 1986; Gottschalk \& Jarrett, 1985) and substrates for the insulin receptor kinase (White et al., 1985; Accili et al., 1986) have been reported, but all await substantiation.

The action of insulin in stimulating glucose transport in adipose tissue and muscle has been intensively studied. Insulin brings about rapid translocation of glucose transporters from an intracellular pool to the plasma membrane (Karnieli et al., 1981 a; Cushman \& Wardzala, 1980). Ignoring potential technical difficulties in assessing glucose transporter number by cytochalasin B binding, insulin also enhances intrinsic activity per transporter unit (Kahn \& Cushman, 1985). In states of insulinopenia or insulin insensitivity, total glucose transporter number decreases and this is likely to reflect lack of insulin effect upon glucose transporter synthesis (Karnieli et al., $1981 b$; Hissin et al., 1982). It must be considered, however, that a decrease in transporter number could reflect a compensatory change in the face of hyperglycaemia. The role of the glucose transporter system in the pathogenesis of hyperglycaemia remains uncertain, as do the mechanisms of translocation to the plasma membrane and change in intrinsic activity.

Studies in vivo in NIDDM. Whereas normal subjects increase glucose utilization by over $300 \%$ during insulin infusion, NIDDM subjects do so by only $30 \%$ (Reaven et al., 1985; Donner et al., 1985; Swislocki et al., 1987). Obesity and NIDDM frequently coexist. Hollenbeck and colleagues have demonstrated that the effect of obesity upon measured insulin sensitivity is similar in normal and NIDDM subjects, and that this effect is small in comparison with the effect of NIDDM per se (Hollenbeck et al., 1984).

The parameter most commonly used to assess insulin sensitivity is tissue uptake of glucose administered intravenously, usually under conditions of hyperinsulinaemia sufficient to inhibit net hepatic glucose production. Hence uptake and storage of glucose as glycogen predominantly in muscle is measured (Rizza et al., 1980; Revers et al., 1984; DeFronzo et al., 1985). As this is increased by mass action during hyperglycaemia, the effect of insulin in hyperglycaemic states may be overestimated. The experimental evidence for insulin insensitivity, gathered in the highly artificial setting of constant hyperinsulinaemia, is corroborated by observations upon diurnal profiles of blood glucose and plasma insulin. Several studies have demonstrated the coexistence of hyperglycaemia and relative hyperinsulinaemia in NIDDM subjects (Swislocki et al., 1987; Liu et al., 1983).

The older techniques of assessment of insulin sensitivity were not able to distinguish between the relative contributions of muscle and liver to the apparent insulin resistance. DeFronzo et al. (1985) demonstrated that during a hyperinsulinaemic euglycaemic clamp approx. $85 \%$ of the intravenously administered glucose was taken up by peripheral tissues (almost entirely muscle). As hepatic glucose production appeared to be reduced to zero under the conditions of the clamp, it was deduced that peripheral tissue insulin insensitivity was the predominant lesion in NIDDM. Methodological problems cause overestimation of the degree of suppression by insulin of hepatic glucose production in NIDDM and normal subjects, but nonetheless hepatic insulin insensitivity appears to contribute relatively little to overall measured insulin sensitivity (Bell et al., 1986; Firth et al., $1986 a$ ).

Studies in vitro in NIDDM. Adipocytes from newly diagnosed NIDDM subjects demonstrate minimal responsiveness to insulin in terms of glucose oxidation or lipogenesis (Bolinder et al., 1982; Hjollund et al., 1985). Interestingly, lipolysis was found to be normally inhibited by insulin in cells from the same subjects (Bolinder et al., 1982). Insulin receptor number has been shown to be normal when measured at $37^{\circ} \mathrm{C}$ (Hjollund et al., 1985; Kashiwagi et al., 1983). One site of defect may be within the insulin receptor itself. Freidenberg et al. (1987) studied insulin receptors partially purified from isolated adipocytes taken from abdominal subcutaneous tissue of moderately obese NIDDM, moderately obese normal and lean normal subjects. The concentration of insulin required for half-maximal stimulation of insulin receptor autophosphorylation was similar for all groups, but that for insulin receptor kinase activity towards the artificial substrate poly(Glu-Tyr) was increased in the NIDDM group only. Obesity per se had no effect on insulin stimulation of kinase activity. Although these data appear to argue for a defect in insulin receptor kinase as an explanation for the post-binding defect characteristic of NIDDM, the results depend on comparison of equal numbers of receptors. Receptor number was determined by extrapolation of a Scatchard plot to the $x$-axis, a notoriously inexact procedure which depends largely on the behaviour of the low-affinity binding. The biological significance of the latter is uncertain. Furthermore, quantification of insulin receptors by one function, binding, in order to assess a second function, kinase activity, presupposes a fixed relation between variables which holds for all insulin receptors. Sinha and colleagues were unable to demonstrate differences in autophosphorylation and kinase activity between receptors prepared from adipose tissue of morbidly obese NIDDM and morbidly obese subjects with normal glucose tolerance (Sinha et al., 1987). In the latter study, data were corrected to equal binding activity of receptor suspensions rather than equal insulin receptor number.

Muscle insulin receptor number has been shown to be about $30 \%$ decreased in very obese subjects with NIDDM or normal glucose tolerance compared with lean subjects (Caro et al., 1987). Insulin receptor kinase activity was decreased to the same extent in the diabetic and normal obese groups, suggesting that diabetes did not further exacerbate the kinase defect of obesity. In streptozotocin diabetes in the rat, insulin receptor number was $60-70 \%$ increased and the insulinstimulated autophosphorylation and kinase activity on exogenous substrates per unit receptor were diminished (Burant et al., 1986). Insulin treatment for 3 days reversed these changes. No studies of viable human muscle in vitro have examined NIDDM, although insulin stimulation in viable human muscle strips has recently been demonstrated with respect to glucose uptake and glycogen synthesis (Dohm et al., 1987; Taylor \& Argyraki, 1987). Limited information is available on substrate concentrations and enzyme activities in needle biopsy specimens of muscle. The studies of Falholt et al. (1985, 1987) have been discussed above. Subnormal insulin stimulation of glycogen synthase in NIDDM subjects was not restored by an 8 week period of good control on insulin therapy (Y. T. Kruzsynska, unpublished work). 
The isolation of viable human hepatocytes presents an important technical advance in metabolic studies (Caro et al., 1986). Hepatocytes from an obese non-diabetic group exhibited a moderate right-shift of the insulin dose-response, but hepatocytes from a NIDDM group failed to increase amino acid uptake rates even at $10^{-7} \mathrm{M}$ insulin. Insulin receptor number was similar in all three groups as judged by insulin binding experiments performed on intact cells at $4{ }^{\circ} \mathrm{C}$. Either patient selection or experimental differences may account for the discrepancy with the results of Arner and colleagues, who found a 2 -fold increase in insulin binding to the liver plasma membranes from NIDDM subjects (Arner et al., 1986).

Studies in IDDM. The insulin sensitivity of glucose disposal in IDDM (DeFronzo et al., 1982b; Proietto et al., 1983) implies that the daily dosage of insulin (U.K. average 52 units/day) is in excess of normal daily secretion rates. This has recently been demonstrated (Polansky et al., 1986). As with NIDDM, errors in interpretation of radioactive tracer methods lead to the supposition that hepatic glucose production is suppressed normally by insulin. It is now apparent that the liver of IDDM subjects is modestly resistant to insulin (Bell et al., 1986).

In contrast with the findings in studies of adipocytes from NIDDM subjects, adipocytes from poorly controlled IDDM subjects displayed increased insulin receptor binding and normal insulin sensitivity with respect to glucose oxidation and lipogenesis (Pedersen \& Hjolland, 1982; Lonnroth et al., 1983; Yki-Jarvinen et al., 1984). It has been suggested that conventional twicedaily injection of insulin causes hyperinsulinaemia which may partially be avoided by continuous subcutaneous insulin infusion. The latter therapy was observed to increase maximally-stimulated rates of glucose transport towards normal without change in either adipocyte insulin binding or insulin sensitivity (Marshall et al., 1988). These data suggest that some of the observed abnormalities in adipose tissue may be secondary to the insulin therapy. Hyperglycaemia itself does not appear to cause insulin resistance, as maintenance of near-normal glycaemia for 6 weeks in a group of previously poorlycontrolled diabetic subjects did not improve insulinstimulated glucose disposal rates (Kruszynska et al., 1986). No changes in the activation state of muscle glycogen synthase either basally or in response to insulin were induced, and the response to insulin was less than in normal subjects.

\section{Glucagon}

Plasma glucagon levels are high in untreated diabetes (Gerich et al., 1976a) and particularly during episodes of diabetic ketoacidosis (Muller et al., 1973), but are rapidly suppressed by insulin treatment (Gerich et al., 1976b; Stark et al., 1987). In IDDM, glucagon secretion in response to hypoglycaemia is frequently blunted or absent. This subnormal response develops within 1-5 years after diagnosis and becomes more marked in later years (Gerich et al., 1973; Benson et al., 1977; Bolli et al., 1983). Impaired glucagon secretion is also observed in NIDDM (Bolli et al., 1984).

Glucagon has a primary role in increasing hepatic glucose output by stimulating glycogenolysis and gluco- neogenesis. In diabetic subjects, inhibition of glucagon secretion markedly suppresses the development of hyperglycaemia after insulin withdrawal (Gerich et al., 1975). The stimulatory effect of a glucagon infusion on glucose output appears transient, because it returns to normal within about 90 min despite persistently high glucagon concentrations, probably due to feedback inhibition via insulin secretion (Bratusch-Marrain et al., 1979). Though the stimulation of glycogenolysis may be transient (Komjati et al., 1985), that of gluconeogenesis is probably sustained because high glucagon levels unaccompanied by appropriate increases in insulin secretion result in a sustained increase in hepatic glucose output (Rizza et al., 1979a,b). At physiological levels, glucagon infusion has been shown to have either no effect on glucose uptake or to cause mild glucose intolerance (Bajorunas et al., 1986); whether the latter is due to a direct effect of glucagon on extrahepatic tissues or to stimulation of catecholamine secretion is not clear. However, studies in vitro using isolated adipocytes have shown that preincubation with glucagon decreases subsequent insulin receptor binding and stimulated glucose transport (Yamauchi \& Hashizume, 1986). Glucagon also has a direct acute stimulatory effect on adipocyte lipolysis (Lefebvre, 1966; Honnor \& Saggerson, 1980). There is little evidence for stimulation of ketogenesis by physiological levels of glucagon in normal man (Liljenquist et al., 1974; Schade \& Eaton, 1976), although increased ketone body levels are observed in subjects made insulin-deficient with somatostatin (Gerich et al., 1976c). In insulin-deprived diabetics, suppression of glucagon secretion with somatostatin impairs ketone body production (Gerich et al., 1975), suggesting that endogenous glucagon contributes to the maintenance of ketogenesis.

\section{Catecholamines}

Catecholamine levels (adrenaline and noradrenaline) are elevated in insulin-dependent diabetics during ketoacidosis or poor metabolic control (Christensen, 1974). In man, adrenaline causes a transient increase in hepatic glucose production (Rizza et al., 1980) mediated through a $\beta$-receptor mechanism, while noradrenaline is weakly hyperglycaemic in normal and insulin-deficient man (Schade \& Eaton, 1978). When glucagon secretion is normal, blockade of the adrenergic receptor system does not modify glucose counter-regulation following insulininduced hypoglycaemia (Rizza et al., 1979a), suggesting that catecholamines may not be essential for glucose homoeostasis in hypoglycaemia. However, during infusion of insulin and somatostatin, to inhibit glucagon secretion, adrenergic blockade prevents the increase in hepatic glucose production in response to hypoglycaemia (Hansen et al., 1986), suggesting that catecholamines might be important for glucose counter-regulation when glucagon secretion is impaired. Adrenaline, noradrenaline and dopamine have been shown to be ketogenic in man; their effect is largely due to stimulation of lipolysis in adipose tissue, but they may also have a direct ketogenic effect on the liver (Keller et al., 1984a; Keller, 1986). Stimulation of the sympathetic nerves in the perfused rat liver increases glucose production and ketogenesis (Beuers et al., 1986), suggesting that noradrenaline may have a role in regulation through sympathetic nerve stimulation. 


\section{Growth hormone}

Plasma GH profiles are elevated in diabetics with longterm complications and poor metabolic control (Fineberg \& Merimee, 1974; Gerich, 1984). It is uncertain whether the high GH levels are the cause or the consequence of the metabolic imbalance. Infusion of physiological levels of $\mathrm{GH}$ in normal and hypophysectomized subjects is associated with an early insulin-like effect on blood glucose followed by insulin resistance. The former is due to increased glucose clearance and suppressed glucose output; the latter is due to impaired suppression of glucose output and decreased glucose clearance (MacGorman et al., 1981 ; Bratusch-Marrain et al., 1982, 1984). Physiological doses of GH increase ketone body levels in man (Schade et al., 1978; Metcalfe et al., 1981; Keller et al., 1984b). This is due to increased lipolysis and possibly also increased ketogenesis at the hepatic level. Although some direct effects of $\mathrm{GH}$ on the liver have been demonstrated, including stimulation of glucose transport and oxidation (Fix \& Moore, 1981), increased activity of phosphatidate phosphohydrolase (Pittner et al., 1986) and acute inactivation of acetyl-CoA carboxylase at micromolar GH concentrations (Bornstein et al., 1983), there is as yet no evidence in vitro for a direct ketogenic effect of $\mathrm{GH}$ on liver cells at physiological hormone levels. In adipose tissue in vitro, acute insulin-like effects of $\mathrm{GH}$ on glucose transport and oxidation, leucine oxidation and glycogen synthesis and stimulation of lipolysis after prolonged exposure are well documented, although the effects are more prominent in adipose tissue from hypophysectomized than from normal animals (Davidson, 1987).

The high GH levels in IDDM have been implicated to be involved in the long-term complications associated with neovascularization (Gerich, 1984). GH regulates the production of insulin-like growth factors (IGF) by the liver, although IGF levels do not always correlate with GH (Herington et al., 1983). IGF I levels are raised in plasma and ocular vitreous in diabetics with proliferative retinopathy (Grant et al., 1986) and evidence in vitro has shown that IGF I increases the proliferation of bovine retinal endothelial cells in culture (King et al., 1985).

\section{Glucocorticoids}

Cortisol excess increases hepatic glucose output and ketogenesis in insulin-deprived diabetics (Barnes et al., 1978) and in normal subjects treated with somatostatin to inhibit insulin secretion, but not when insulin secretion is unimpaired (Johnston et al., 1982). High cortisol levels have been observed in diabetic ketosis and have been implicated to aggravate increased lipolysis in adipose tissue and increased fractional diversion of fatty acids towards mitochondrial ketogenesis at the hepatic level (Johnston \& Alberti, 1982). Glucocorticoid increased ketogenesis and gluconeogenesis in rat hepatocytes in the absence of insulin, but not in its presence (Agius et al., $1986 a$ ). The stimulatory effect is much smaller than that of glucagon, supporting the clinical evidence that cortisol has a relatively minor role as regulator of ketogenesis.

\section{INSULIN SECRETION}

Physiologically, plasma glucose concentration is a major regulator of insulin secretion. This effect may be mimicked and potentiated by amino acids (Floyd et al.,
1966), potentiated by glucose insulinotropic peptide (Dupre et al., 1973; Jones et al., 1987) and inhibited by catecholamines which act predominantly via the $\alpha$ adrenergic receptors (Robertson et al., 1976). Whether the signal for insulin release is generated by a glucose receptor such as the glucose transporter or by a step in the metabolism of glucose remains uncertain. It has been argued that the capacity of molecules to stimulate insulin secretion is directly proportional to their suitability as $\beta$ cell fuels for glycolysis (Âshcroft, 1981 ; Sener \& Malaisse, 1984). Glyceraldehyde and pyruvate are respectively good and ineffective insulin secretagogues (Zawalich et al., 1978; Sener et al., 1978). Whatever the precise nature of the initiating signal, it is clear that insulin release is closely associated with a rise in intracellular free calcium (Rorsman et al., 1984). However, under a number of experimental conditions, glucose brings about a paradoxical decrease in intracellular free calcium. Glucose affects cellular uptake and efflux of $\mathrm{Ca}^{2+}$ and movement of free $\mathrm{Ca}^{2+}$ into organelle-bound calcium, these processes exhibiting different latencies (for review see Hellman, 1986).

Assessment of pancreatic $\beta$ cell capacity/responsiveness in NIDDM is complicated by prevailing blood glucose concentrations. Although NIDDM subjects have no absolute deficiency of insulin as assessed by diurnal plasma insulin profiles (Liu et al., 1983) and normal or raised fasting plasma insulin (DeFronzo \& Ferrannini, 1982) this cannot be interpreted as indicating normality of $\beta$ cell function. When normal subjects are examined during hyperglycaemia, resulting rates of insulin secretion are far higher than in equivalently hyperglycaemic NIDDM subjects (Halter et al., 1979; Ferner et al., 1986). Conversely, when NIDDM subjects are rendered normoglycaemic by prior insulin infusion, steady state insulin levels after a wash-out period are lower than in weight-matched normal subjects (Turner et al., 1976).

Following an intravenous bolus of glucose, first phase insulin release is absent in NIDDM subjects, and indeed a temporary sharp decrease in insulin secretion rates is occasionally observed (Brunzell et al., 1976; Metz et al., 1979; Hellman, 1986). Although it is frequently assumed that second phase insulin release is not grossly abnormal in NIDDM, it is dependent upon the degree of hyperglycaemia (Ferner et al., 1986).

Initial assessment of the effect of such non-glucose insulin secretagogues as isoproterenol or arginine suggested that $\beta$ cells of NIDDM subjects responded normally (Pfeifer et al., 1981). Examination of the slope of glucose potentiation demonstrated that, although the insulin response to arginine in NIDDM subjects at a blood glucose around $22 \mathrm{mmol} / 1$ was equivalent to that of normal subjects, the latter exhibited a 5-fold enhancement of response when blood glucose was raised to $22 \mathrm{mmol} / 1$ (Robertson \& Chen, 1977; Ward et al., 1984). The glucose level required for half-maximal responsiveness to arginine was normal in NIDDM. These findings imply a generalized loss of $\beta$ cell capacity rather than a problem of glucose sensing as the basis of the insulin secretory abnormality in NIDDM. In support of this, post mortem studies have suggested a 40-60\% decrease in mean $\beta$ cell mass in NIDDM (Saito et al., 1979; Gepts \& Lecompte, 1981). A 70-90\% pancreatectomy does not usually bring about overt diabetes (Brooks, 1979), emphasizing the importance of concurrence of a moderate decrease in both $\beta$ cell function and tissue 
sensitivity in the pathogenesis of NIDDM. Dysfunction of a normal number of $\beta$ cells induced by somatostatin in man and partial pancreatectomy in the rat both give rise to impaired first and second phase insulin responses to glucose and normal responses to non-glucose stimuli (Ward et al., 1983; Leahy et al., 1984).

\section{Early defects in insulin secretion in IDDM}

It is now recognized that IDDM is a disease of slow onset, even though clinical presentation may be sudden and dramatic (Tarn et al., 1987). The preclinical phase may last for 5 years or more, may be characterized by a fluctuating rate of $\beta$ cell attrition (Spencer $e t$ al., 1984) and first phase insulin response may decrease slowly before disappearing (Srikanta et al., 1983). It is highly likely that an immunological attack causes the progressive $\beta$ cell damage (Bottazzo, 1986). However, immunological $\beta$ cell attack may not always progress to IDDM, and mild abnormalities in insulin secretion may result (Millward et al., 1986; Heaton et al., 1987). The potential for halting the immunological damage has led to clinical studies of the effect of the immunosuppressive agent cyclosporin A. Although early results appear encouraging, it is possible that spontaneous fluctuations in disease progression or 'honeymoon phase' may explain these data (Stiller et al., 1984; Assan et al., 1985).

\section{THERAPEUTIC ASPECTS}

\section{Mechanism of action of sulphonylureas}

Sulphonylureas have a pronounced acute effect in stimulating insulin release (Yalow et al., 1960). However, sulphonylureas potentiate insulin action in recently pancreatectomized animals (Houssay et al., 1957; Caren \& Corbo, 1959) and they inhibit lipolysis and ketogenesis, in addition to enhancing glycogen and non-esterified fatty acid synthesis in vitro apparently independently of insulin (Stone \& Brown, 1967; Boshell et al., 1960; Fleig et al., 1984, Salhanick et al., 1983). Chronic administration of sulphonylureas is not associated with persistence of insulinotropic effects (Duckworth et al., 1972). A direct drug effect on tissue insulin sensitivity has been claimed (Kolterman et al., 1984; Ward et al., 1985), although contrary evidence exists (Marchand et al., 1985). The positive studies are open to interpretation, as enhanced insulin sensitivity may be a secondary effect of improved metabolic control, whether achieved by dietary means (Pedersen et al., 1981), exercise (Yki-Yarvinen et al., 1984), or insulin therapy (Andrews et al., 1984; Garvey et al., 1985). Studies on isolated cells in vitro have produced similarly discordant results (Vigneri et al., 1982; Goldfine et al., 1984; Altan et al., 1985; Ward et al., 1985).

Studies in vivo of sulphonylurea effects in NIDDM are difficult to interpret, as any direct drug effect cannot be separated from secondary effects mediated via increased insulin secretion or improved metabolic control. In IDDM subjects, lacking any insulin secretory capacity, no effect on tissue insulin sensitivity could be detected (Grunberger et al., 1982; Keller, 1986). However, Pernet and colleagues demonstrated that at low insulin infusion rates sufficient to achieve moderate physiological levels of insulin, glibenclamide appeared to enhance the insulinmediated glucose disposal (Pernet et al., 1985). As this effect could not be seen at higher insulin levels, it is possible that it reflects an alteration in hepatic rather than peripheral tissue metabolism.

The observation of a raised plasma insulin to $\mathrm{C}$ peptide ratio has led to the suggestion that decreased hepatic insulin extraction is a direct drug effect (BeckNielsen et al., 1986; Scheen et al., 1984; Kolterman et al., 1983). Tolbutamide decreases insulin extraction in the perfused rat liver (Marshall et al., 1970). If this is the case, the lesser amount of insulin interacting with and taken up by hepatocytes is relatively more potent in decreasing net hepatic glucose output in the presence of the drug.

\section{Mechanism of action of metformin}

Metformin does not increase plasma insulin concentrations and it has been postulated to act by decreasing gluconeogenesis (Meyer et al., 1967; Jackson et al., 1987b; Nosadini et al., 1987) or increasing insulinmediated glucose disposal (Prager et al., 1986; Nosadini et al., 1987; Pagano et al., 1983). In vitro, metformin increases basal but not maximal, insulin-stimulated rates of glucose oxidation in rat fat cells (Fantus \& Brosseau, 1986) and enhances insulin-mediated glucose uptake in muscle of diabetic rodents (Bailey \& Puah, 1986; Frayn \& Adnitt, 1972). In NIDDM subjects, metformin appears to increase insulin-mediated glucose uptake (Prager et al., 1986; Nosadini et al., 1987). This concurs with previous studies on phenformin action in the human forearm (Butterfield et al., 1961), supporting a direct drug effect. Metformin administration to IDDM subjects brought about a slight increase in maximal insulinstimulated glucose uptake rates (Gin et al., 1985) and a decrease in daily insulin requirements (Prager et al., 1986; Nosadini et al., 1987). However, Jackson et al. (1987a), studying a group of NIDDM subjects who exhibited a good response to metformin treatment, found no evidence for an increase in muscle glucose uptake after an oral load. Rather, the improvement in glycaemic control appeared to be due to decreased hepatic glucose output (Jackson et al., 1987a). The glucose tolerance curve was not changed in shape but started from a lower point. There is evidence for a metformin-induced decrease in gluconeogenesis but not hepatic glycogenolysis (Meyer et al., 1967; Haeckel \& Haeckel, 1982). Unless glycogenolysis accounts for a lesser proportion of fasting hepatic glucose output in NIDDM than normal subjects, it must be involved in any substantial reduction in hepatic glucose output. A general increase in hepatic insulin sensitivity could account for the observations. The effects of metformin in increasing plasma arterial lactate concentrations may be interpreted as confirming the drug-induced inhibition of gluconeogenesis (Jackson et al., 1987a), since metformin does not increase lactate production in the forearm of NIDDM subjects in vivo (Jackson et al., 1987a).

\section{Effects of dietary therapy}

Dietary composition affects metabolic control in subjects with impaired glucose tolerance and diabetes. Prescription of low carbohydrate diets for all diabetic subjects was the norm until 1984, and this inevitably led to consumption of a high fat diet. This was unsound in view of the propensity of diabetic subjects to ischaemic heart disease and hyperlipidaemia. The observation that diets with a high proportion of unrefined carbohydrate improved metabolic control was of great interest. Such 
diets have been shown to improve insulin sensitivity in vivo and in isolated adipocytes (Hjollund et al., 1983, 1987). Although some studies suggest that addition of sucrose to the diet of NIDDM subjects does not affect glycaemic control under experimental conditions (Bantle et al., 1983), the hyperlipidaemic effect of added sucrose (Coulston et al., 1985) has been demonstrated.

Many NIDDM subjects are obese. A weight loss averaging $6.7 \mathrm{~kg}$ produced no changes in insulinmediated glucose uptake at physiological insulin concentrations nor in adipocyte metabolism in vitro (Zawadzki et al., 1987). In a similar group, weight loss of $16.8 \mathrm{~kg}$ average was associated with a decrease in hepatic glucose output despite no change in fasting plasma insulin, and increased glucose uptake at high physiological plasma insulin levels was enhanced (Henry et al., 1986). The unchanged fasting plasma insulin levels despite a pronounced decrease in blood glucose suggests that $\beta$ cell sensitivity to glucose is improved.

\section{Effect of insulin treatment}

Although the titles of the early studies on the effect of insulin therapy on insulin sensitivity in NIDDM suggested that it could be returned to normal (Scarlett et al., 1982, 1983), the data were less impressive. Hepatic sensitivity to insulin may be increased at only modest improvement in glycaemic control when peripheral tissue insulin sensitivity is unaffected (Nankervis et al., 1982). The improvement seen in peripheral tissue insulin sensitivity appears to be most marked in the least obese individuals (Andrews et al., 1984). However, the minor nature of the changes in tissue sensitivity are emphasized by the observation that fasting plasma glucose and glucose intolerance return to pretreatment levels shortly after insulin withdrawal, whereas the changes in tissue sensitivity persist for up to 6 weeks (Gormley et al., 1986). Insulin therapy in NIDDM improves insulin secretion in response to glucagon (Garvey et al., 1985) and oral glucose (Andrews et al., 1984; Gormley et al., 1986; Hidaka et al., 1982). Unfortunately, few of these studies looked at lipid metabolism in an attempt to establish whether or not changes in insulin action may be related to changes in NEFA levels (Randle et al., 1963). Improvement of diabetic control from abysmal to poor was associated with a reduction in fasting NEFA and ketone bodies (Nankervis et al., 1982).

As improvement of metabolic control by exogenous insulin and sulphonylurea administration results in similar changes in hepatic glucose output or peripheral tissue insulin sensitivity, it is quite possible that neither therapy acts directly on insulin sensitivity, but that some aspect of the metabolic state itself is responsible (Firth et al., 1986b). Indeed, dietary therapy alone decreases fasting blood glucose and improves insulin-stimulated rates of glucose oxidation (Boden et al., 1983). Decrease in circulating NEFA improves glucose utilization (Randle et al., 1963), but unfortunately NEFA, intermediary metabolites and counter-regulatory hormones were not measured in the majority of above studies. It may be hypothesized that only one of several concurrent defects is modified by insulin therapy.

Conventional subcutaneous insulin administration results in slow absorption from the site of injection throughout the day and hyperinsulinaemia in the systemic but not portal circulation. Hence, even when blood glucose is almost normalized on such a regime, abnormalities in plasma free insulin levels and intermediary metabolites remain. Achievement of strict normoglycaemia by intravenous insulin administration still requires hyperinsulinaemia (Nosadini et al., 1982). Administration of insulin directly into the portal system by intraperitoneal delivery does indeed reduce the hyperinsulinaemia (Jimenez et al., 1985; Husband et al., 1984). The normalization of carbohydrate and lipid metabolism in diabetic dogs by intraportal but not intravenous insulin administration has been reported (Stevenson et al., 1983a,b). However, intraportal islet transplantation with peripheral venous drainage normalized glucose tolerance (Guy et al., 1987). The results of studies currently under way into the metabolic effects of relatively hepatospecific insulins will be of great interest.

\section{NEW THERAPIES FOR DIABETES}

Tetradecylglycidate (methyl palmoxirate) and Etomoxir are oxirane carboxylic acids whose CoA esters inhibit carnitine palmitoyltransferase I, thereby preventing mitochondrial long chain fatty acid oxidation. This might be expected to increase glucose utilization via the glucose-fatty acid cycle and indeed these compounds are hypoglycaemic in fasting animals (Tutwiler et al., 1978; Eistetter \& Wolf, 1982). Suggestion of an action in inhibiting gluconeogenesis in animals and man is of great interest (Selby et al., 1987).

Carnitine palmitoyltransferase inhibition only inhibits fatty acid oxidation. The flux-generating step for fatty acid metabolism is lipolysis. Nicotinic acid inhibits lipolysis in adipose tissue and thus lowers plasma NEFA levels. Oral administration of the nicotinic acid analogue, Acipimox, is followed by a decrease in glycerol, NEFA and 3-hydroxybutyrate levels by approx. $80 \%$ within $2 \mathrm{~h}$, and an improvement in glucose tolerance and peripheral glucose uptake (Piatti et al., 1987).

The $\alpha$-glucosidase inhibitor acarbose and its newer derivative Bay $\mathrm{m} 1099$ have been shown to have dramatic effects in decreasing postprandial excretions of glucose, lactate and pyruvate in normal and diabetic subjects. Despite the marked postprandial changes in blood glucose profiles, overall indices of glycaemic control in diabetic subjects have been remarkably little changed (Lardinois et al., 1984; Samad et al., 1988). The role of such substances in the management of diabetic patients remains speculative.

\section{CHRONIC COMPLICATIONS OF DIABETES}

Longterm diabetes brings about distinct abnormalities in the microcirculation and in nervous function which are clinically manifested as nephropathy, retinopathy and neuropathy. The risk of developing such complications is related to longterm average glycaemic control (Tchobroutsky, 1978; Pirart, 1978), but a component of genetic susceptibility to complications means that not all individuals with relatively good diabetic control escape problems and that some individuals can endure metabolic mayhem over decades without apparent problems. In addition, but unrelated to degree of glycaemic control, arterial.disease is manifested as coronary heart disease and peripheral vascular disease. 


\section{Basement membrane thickening}

Thickening of basement membranes is a universal finding in longstanding diabetes. After 5 years of clinical diabetes, basement membranes are 25-30\% thicker than in normal subjects (Osterby et al., 1986). The basement membrane matrix, composed of type IV collagen and laminin, is more permeable in diabetes, and thickening may represent a compensatory change (Rohrbach et al., 1982). The role of collagen glycosylation in the pathogenesis of the basement membrane abnormality remains to be elucidated (Cohen et al., 1980), but it is clear that basement membrane thickening does not antedate metabolic disturbance (Osterby, 1975). Tight metabolic control can partially reverse basement membrane thickening (Raskin et al., 1983).

\section{Non-enzymic glycosylation}

Enzymic glycosylation is a highly regulated posttranslational process responsible for conferring specific structural and functional changes on proteins (Uy \& Wold, 1977). In contrast, non-enzymic glycosylation is governed solely by prevailing glucose concentration. Lysine and valine residues undergo rapid aldimine (Schiff base) and subsequently ketoamine formation. Advanced glycosylation endproducts ultimately result. If affected amino acids are close to the active sites of their molecule, or if stereochemical configuration is disturbed, then function will be altered. Thus glycosylated albumin inhibits hepatic uptake of glycoproteins (Summerfield et al., 1982). Glycosylated fibrin is less susceptible to fibrin digestion (Brownlee et al., 1983), thus making any thrombus more likely to result in permanent vascular occlusion. Glycosylation of apoprotein B causes a reduction of affinity for the low density lipoprotein receptor (Kesaniemi et al., 1983). Glycosylated collagen displays increased intramolecular cross-linkings (Kohn \& Schnider, 1982) and this may underly the decreased small joint mobility of longstanding diabetes. The latter has been claimed to be an indicator for the development of microvascular complications (Rosenbloom et al., 1983). As red blood cells have a relatively constant halflife, estimation of the percentage of haemoglobin which has been glycosylated gives a reliable index of average glycaemic control over the preceding 2 months (Bunn, 1981). This index is invaluable for clinical and research purposes.

\section{Relevance of the sorbitol pathway}

In the ocular lens particularly, sorbitol concentrations are grossly elevated in diabetic rats, and this may be related to formation of cataracts, at least of the acute type (Gabbay, 1973). Glucose, sorbitol and fructose concentrations are elevated in the nerves of diabetic animals and man (Ward et al., 1972; Greene et al., 1975; Greene \& Mackway, 1986; Dyck et al., 1980). Although initially it was postulated that the osmotic effect of these changes could cause cellular oedema, Schwann cells from diabetic rats have a decreased volume (Jacobsen, 1978) and calculated osmolar changes are very small.

Both treatment with aldose reductase inhibitors and dietary myo-inositol supplementation reverses neural depletion of myo-inositol and corrects abnormalities in $\mathrm{Na}^{+} / \mathrm{K}^{+}$-ATPase and axonal transport (Greene \& Lattimer, 1984; Tomlinson \& Mayer, 1984). Treatment of human diabetic neuropathy with myo-inositol or aldose reductase inhibitors has not yielded clearcut answers. Clinical and electrophysiological improvements have been documented after myo-inositol therapy in some (Greene et al., 1981; Salway et al., 1978; Clements et al., 1979) but not all (Gregersen et al., 1978, 1983; Greene et al., 1981) studies. Aldose reductase inhibitor therapy brought about small but significant improvements in motor, sensory and autonomic nerve function in the majority of studies (Judzewitsch et al., 1983; Fagius et al., 1985; Jaspan et al., 1985). Other studies failed to demonstrate any benefit (Handlesman \& Turtle, 1981). A degree of symptomatic improvement in painful neuropathy follows aldose reductase inhibition (Young et al., 1983; Koglin et al., 1985). As glucose competes with myo-inositol for active transport into nerves, hyperglycaemia per se results in myo-inositol depletion. Maintenance of near normoglycaemia for 4-8 months results in some improvement in symptomatic and objective measures of nerve function (Boulton et al., 1982; Service et al., 1985). The chronic neuropathy of longstanding diabetes is at least in part secondary to irreversible microvascular disease, and endoneurial oxygen tension is low (Low et al., 1985). In such circumstances metabolic manipulation is obviously too late.

Glucose uptake by the retina is insulin-independent, and the retina depends for its energy supply upon anaerobic glycolysis. Aldose reductase inhibitors prevent loss of retinal capillary pericytes and basement membrane thickening, which are thought to be associated with polyol pathway activation (Robison et al., 1983, 1985). Retinal pericytes contain aldose reductase (Akagi et al., 1983). Loss of retinal pericytes could induce some of the retinal capillary changes observed in diabetes.

\section{Atherogenesis}

Diabetes is a major risk factor for atherogenesis and arterial disease. Elevated low density lipoprotein cholesterol may result from glycosylation of the lysyl residues of apoprotein B, decreased affinity for the low density lipoprotein receptor and hence decreased metabolism (Kesaniemi et al., 1983). It remains to be established whether elevation of plasma lipids is a necessary pathogenic state or merely a marker for atherogenesis. Lipid synthesis in situ in the arterial wall may occur, and increased activity of glucose-6-phosphate dehydrogenase has been demonstrated in muscle and aortas of hyperinsulinaemic pigs and muscle of NIDDM subjects (Stout, 1979; Falholt et al., 1985a, 1987). The peripheral hyperinsulinaemia of NIDDM and of insulin-treated subjects would stimulate lipogenesis in situ and in this context the epidemiological association between raised serum insulin levels and cardiovascular disease is of interest.

\section{CONCLUSION}

More questions about the biochemical basis of diabetes remain than have been answered to date. In particular, hormone insensitivity, the reversal of such insensitivity, metabolic interactions between tissues and the pathogenesis of chronic complications are areas of very uncertain knowledge. Current research on these difficult questions will provide a basis for advances both in understanding and therapy. 
We are grateful to George Alberti for critical comments, Peter Selby, Ian Jones, and Pierro Piatti for permitting mention of unpublished data, and Ann Potts for expert wordprocessing.

\section{REFERENCES}

Accili, D., Perrotti, N., Rees-Jones, R. \& Taylor, S. I. (1986) Endocrinology (Baltimore) 119, 1274-1280

Agius, L, Chowdhury, M. H. \& Alberti, K. G. M. M. (1986a) Biochem. J. 239, 593-601

Agius, L., Chowdhury, M. H., Davis, S. N. \& Alberti, K. G. M. M. (1986b) Diabetes 35, 1286-1293

Akagi, Y., Kador, P. F., Kuwabara, T. \& Kinoshita, J. J. (1983) Invest. Ophthalmol. Vis. Sci. 24, 1516-1519

Alberti, K. G. M. M., Dornhorst, A. \& Rowe, A. S. (1975) Isr. J. Med. Sci. 2, 571-580

Altan, N., Altan, V. M., Mikolay, L., Larner, J. \& Schwartz, C. F. W. (1985) Diabetes 34, 281-286

Andrews, W. J., Vasquez, B., Nagulesparan, M., Klimes, I., Foley, J. \& Reaven, G. M. (1984) Diabetes 33, 634-642

Argiles, J. M. (1986) Trends Biochem. Sci. 11, 61-63

Arner, P., Einarsson, K., Ewerth, S. \& Livingston, J. (1986) J. Clin. Invest. 77, 1716-1718

Ashcroft, S. J. H. (1981) in The Islets of Langerhans (Cooperstein, S. J. \& Watkins, D., eds.), pp. 117-148, Academic Press, New York

Assan, R., Feutren, G., Debray-Sachs, M., Quiniou-Dibric, M. C., Laboric, C., Thomas, G., Chatenoud, L. \& Bach, J. F. (1985) Lancet i, 67-71

Bagdade, J. D., Porte, D. \& Bierman, E. L. (1968) Diabetes 17, 127-132

Bailey, C. J. \& Puah, J. A. (1986) Diabete Metab. 12, 212-218

Bajorunas, D. R., Dreslen, C. M., Horowitz, G. D., McDermott, K., Jeevanandam, M., Fortnen, J. D. \& Brennam, M. F. (1986) Diabetes 35, 556-562

Bantle, J. P., Laine, D. C. \& Castle, J. W. (1983) N. Engl. J. Med. 309, 7-12

Barnes, A. J., Johnston, D. G., Kohner, E. M., Alberti, K. G. M. M., Bloom, S. R. \& Smythe, P. (1978) Lancet i, 1171-1174

Beck-Nielsen, H., Hother-Nielsen, O., Andersen, P. H., Pedersen, O. \& Schmitz, O. (1986) Diabetologia 29, 515A

Bell, P. M., Firth, R. G. \& Rizza, R. A. (1986) J. Clin. Invest. 78, 1479-1486

Benson, J. W., Johnson, D. G., Palmer, J. P., Werner, P. L. \& Ensinck, J. W. (1977) J. Clin. Endocrinol. Metab. 44, 459-464

Beuers, U., Beckh, K. \& Jungermann, K. (1986) Eur. J. Biochem. 158, 19-24

Boden, G., Ray, R. K., Smith, R. H. \& Owen, O. E. (1983) Diabetes 32, 962-987

Bogardus, C., Lillioja, S., Howard, B. V., Reaven, G. \& Mott, D. (1984) J. Clin. Invest. 74, 1238-1246

Bolinder, J., Ostman, J. \& Arner, P. (1982) Diabetes 31, 911-916

Bolli, G., De Feo, P., Compagnucci, P., Cartechini, M. G., Angeletti, G., Santeusanie, F., Brunetti, P. \& Gerich, J. E. (1983) Diabetes 32, 134-141

Bolli, G. B., Tsolikian, E., Haymond, M. W., Cryer, P. E. \& Gerich, P. E. (1984) J. Clin. Invest. 73, 1532-1541

Bornstein, J., Ng, F. M., Heng, D. \& Wong, K. P. (1983) Acta Endocrinol. 103, 479-486

Boshell, B. R., Zahnd, E. R. \& Renold, A. E. (1960) Diabetes 8, 21-29

Bottazzo, G. G. (1986) Diabet. Med. 3, 119-130

Boulton, A. J. M., Drury, J., Clarke, B. \& Ward, J. D. (1982) Diabetes Care 5, 386-390

Bratusch-Marrain, P., Björkman, O., Hagenfeldt, L., Waldhausl, W. \& Wahren, J. (1979) Diabetes 28, 126-131
Bratusch-Marrain, P. R., Smith, D. \& DeFronzo, R. A. (1982) J. Clin. Endocrinol. Metab. 5, 973-982

Bratusch-Marrain, P. R., Sobodan, G., Walhausl, K. \& Kowotony, P. (1984) Diabetes 33, 19-25

Brooks, J. R. (1979) Semin. Oncol. 6, 357-367

Brownlee, M., Vlarsara, H. \& Cerami, A. (1983) Diabetes 32, 680-684

Brunzell, J. D., Robertson, R. P., Lerner, R. L., Hazzard, M. R., Ensinck, J. W., Bierman, E. L. \& Porte, D., Jr. (1976) J. Clin. Endocrinol. Metab. 42, 222-229

Bunn, H. F. (1981) Diabetes 30, 613-617

Burant, C. F., Treutelaar, K. \& Buse, M. G. (1986) J. Clin. Invest. 77, 260-270

Butterfield, J., Fry, I. K. \& Whickelow, M. (1961) Lancet ii, 563-567

Capaldo, B., Home, P. D., Massi-Benedetti, M., Worth, R., Cook, D. B., Heaton, A. \& Alberti, K. G. M. M. (1984) Diabetes Res. 1, 187-193

Caren, R. \& Corbo, L. (1959) J. Clin. Invest. 36, 1546-1550

Caro, J. F., Ittoop, O., Pories, W. J., Meelheim, D., Flickinger, E. G., Thomas, F., Jenquin, M., Silverman, J. F., Khazanie, P. G. \& Sinha, M. K. (1986) J. Clin. Invest. 78, 249-258

Caro, J. S., Sinha, M. K., Raju, S. M., Ittoop, O., Pories, W. J., Flickinger, E. G. Meelheim, D. \& Dohm, G. L. (1987) J. Clin. Invest. 79, 1330-1337

Cassava, J. P., Felves, M. E. \& Veech, R. L. (1984) J. Biol. Chem. 259, 231-236

Chou, C. K., Dull, T. J., Russell, D. S., Gherzi, R., Lebwohl, D., Ullrich, A. \& Rosen, O. M. (1986) J. Biol. Chem. 262, 1842-1847

Christensen, N. J. (1974) Diabetes 23, 1-8

Clements, R. S., Jr., Vourganti, B. \& Kuba, T. (1979) Metabolism 28 (Suppl. 1), 477-483

Cohen, M. P., Urdanivia, E., Surma, M. \& Wu, V. Y. (1980) Biochem. Biophys. Res. Commun. 95, 765-769

Coulston, A. M., Hollenbeck, C. B., Donner, C. C., Williams, R., Chiou, Y. A. M. \& Reaven, G. M. (1985) Metabolism 34, 962-966

Cushman, S. W. \& Wardzala, L. J. (1980) J. Biol. Chem. 255, 4758-4762

Das, B. \& Srivastava, S. K. (1985a) Arch. Biochem. Biophys. 238, 670-679

Das, B. \& Srivastava, S. K. (1985b) Diabetes 34, 1145-1151

Davidson, M. B. (1987) Endocr. Rev. 8, 115-131

Davis, S., Butler, P. C., Brown, M. D., Hanning, I., Hales, C. N., Home, P. D. \& Alberti, K. G. M. M. (1986) Diabetes 35, 28A

DeFronzo, R. A. \& Ferrannini, E. (1982) Medicine 61, 125-140

DeFronzo, R. A., Simonson, D. \& Ferrannini, E. (1982a) Diabetologia 23, 313-319

DeFronzo, R. A., Hendler, R. \& Simonson, D. (1982b) Diabetes 31, 795-801

DeFronzo, R. A., Gunnarsson, R., Bjorkman, O., Olsson, M. \& Wahren, J. (1985) J. Clin. Invest. 76, 149-155

Denton, R. M., Brownsey, R. W. \& Belsham, G. J. (1981) Diabetologia 21, 347-362

Dohm, G. L., Tapscott, E. B., Pories, W. J., Dabbs, D. J., Flickinger, E. G., Meelheim, D., Fushiki, T., Atkinson, S. M. \& Caro, J. F. (1987) Diabetes 36 (Suppl. 1), 50A

Donner, C. C., Fraze, E., Chen, Y.-D. I. \& Reaven, G. M. (1985) Diabetes 34, 831-835

Duckworth, W. C., Solomon, S. \& Kitabchi, A. E. (1972) J. Clin. Endocrinol. Metab. 35, 585-591

Dunn, F. L., Raskin, P., Bilheimer, D. W. \& Grundy, S. M. (1984) Metabolism 33, 117-123

Dunn, F. L., Carroll, P. B. \& Beltz, W. F. (1987) Diabetes 36, 661-666

Dupre, J., Ross, S. A., Watson, D. \& Brown, J. C. (1973) J. Clin. Endocrinol. Metab. 37, 826-828 
Durrington, P. N., Newton, R. S. \& Weinstein, D. B. (1982) J. Clin. Invest. 70, 63-73

Dyck, P. J., Sherman, W. R., Hallcher, L. M., Service, F. J., O'Brien, P. C., Grina, L. A., Palumbo, P. J. \& Swanson, C. J. (1980) Ann. Neurol. 8, 590-596

Eistetter, K. \& Wolf, H. P. O. (1982) J. Med. Chem. 25, 109-113

Ellis, L., Clauser, E., Morgan, D. O., Edery, M., Roth, R. A. \& Rutter, W. J. (1986) Cell 45, 721-732

Fagius, J., Brattherg, A., Berne, C. \& Jameson, S. (1985) Diabetologia 28, 323-329

Falholt, K., Alberti, K. G. M. M. \& Heding, L. G. (1985a) Diabetologia 28, 32-37

Falholt, K., Calfield, R., Heding, L. G. \& Mintz, D. (1985b) Metabolism 34, 1146-1149

Falholt, K., Jensen, M. D., Jensen, L., Mortensen, H., Volund, A., Heding, L. G. \& Falholt, M. D. (1988) Diabetic Med., in the press

Fantus, I. G. \& Brosseau, R. (1986) J. Clin. Endocrinol. Metab. 63, 898-905

Ferner, R. E., Ashworth, L., Tronier, B. \& Alberti, K. G. M. M. (1986) Am. J. Physiol. 250, E655-E661

Fery, F. \& Balasse, E. O. (1985) Diabetes 34, 326-337

Fineberg, S. E. \& Merimee, T. J. (1974) Diabetes 23, 499-504

Firth, R. G., Bell, P. M., Marsh, H. M., Hansen, L. \& Rizza, R. A. (1986a) J. Clin. Invest. 77, 1525-1532

Firth, R. G., Bell, P. M. \& Rizza, R. A. (1986b) N. Engl. J. Med. 314, 1280-1286

Fix, J. A. \& Moore, W. V. (1981) Endocrinology (Baltimore) 108, 239-246

Floyd, J. C., Fafans, S. S., Conn, J. W., Knopf, R. F. \& Rull, J. (1966) J. Clin. Invest. 45, 1487-1502

Fleig, W. E., Noether-Fleig, G., Fussgaenger, R. \& Ditschuneit, H. (1984) Diabetes 33, 285-290

Forsayeth, J. R., Caro, J. F., Sinha, M. K., Maddux, B. A. \& Goldfine, I. D. (1987) Proc. Natl. Acad. Sci. U.S.A. 84, 3448-3451

Frayn, K. N. \& Adnitt, P. I. (1972) Diabetes 21, 3153-3162

Fraze, E., Donner, C. C., Swislocki, A. L. M., Chiou, Y.-A. M., Chen, Y.-D. I. \& Reaven, G. M. (1985) J. Clin. Endocrinol. Metab. 61, 807-811

Freidenberg, G. R., Henry, R. R., Klein, H. H., Reichart, D. R. \& Olefsky, J. M. (1987) J. Clin. Invest. 79, 240-250

Gabbay, K. H. (1973) N. Engl. J. Med. 288, 831-836

Gamble, S. A. \& Cook, G. A. (1985) J. Biol. Chem. 260, 9516-9519

Garvey, W. T., Olefsky, J. M., Griffin, J., Hamman, R. F. \& Kolterman, O. G. (1985) Diabetes 34, 222-234

Gepts, W. \& Lecompte, P. M. (1981) Am. J. Med. 70, 105-114

Gerich, J. E. (1984) N. Engl. J. Med. 310, 848-850

Gerich, J. E., Langlois, M., Noacca, C., Karam, J. H. \& Forsham, P. H. (1973) Science 182, 171-173

Gerich, J., Lorenzi, M., Bier, D., Schneider, V., Salikian, E., Karam, J. \& Forsham, P. (1975) N. Engl. J. Med. 292, 985-989

Gerich, J. E., Langlois, M., Noacca, C., Lorenzi, M., Karam, J. H. \& Forsham, P. H. (1976a) J. Clin. Invest. 58, 320-325

Gerich, J., Lorenzi, M., Tsalikian, E., Bohennan, N., Schneider, V., Karam, J. \& Forsham, P. (1976b) Diabetes 25, 955-960

Gerich, J. E., Lorenzi, M., Bies, D. M., Tsalikian, E., Schneider, V., Karam, H. J. \& Forsham, P. H. (1976c) J. Clin. Invest. 57, 875-884

Gibbons, G. F. (1986) Clin. Sci. 71, 477-486

Gin, H., Messerschmitt, C., Borttier, E. \& Aubertin, J. (1985) Metabolism 34, 923-925

Gonzalez, A. M., Sochor, M. \& McLean, P. (1983) Diabetes 32, 482-485

Gonzalez, R. G., Barnett, P., Aguayo, J., Cheng, H.-M. \& Chylack, L. T. (1984) Diabetes 33, 196-199
Gonzalez, A. M., Sochor, M., Hothersall, J. S. \& McLean, P. (1986) Diabetes 38, 1200-1205

Goldfine, I. D., Iwamoto, Y., Ezino, V., Trischitta, V., Proello, F. \& Vigneri, R. (1984) Diabetes Care 7 (Suppl. 1), 54-58

Gormley, M. J. J., Hadden, D. R., Woods, R., Sheridan, B. \& Andrews, W. J. (1986) Metabolism 35, 1029-1036

Gottschalk, W. K. \& Jarett, L. (1985) Diabetes Metab. Rev. 1, 229-269

Grant, M., Russell, B., Fitzgerald, C. \& Merimee, T. J. (1986) Diabetes 39, 416-420

Greene, D. A. \& Lattimer, S. S. (1984) Diabetes 33, 712-716

Greene, D. A. \& Mackway, A. M. (1986) Diabetes 35, 1106-1108

Greene, D. A., DeJesus, P. V. \& Winegrad, A. I. (1975) J. Clin. Invest. 55, 1326-1336

Greene, D. A., Brown, M. J., Braunstein, S. N., Schwartz, S. S., Asbury, A. K. \& Winegrad, A. I. (1981) Diabetes 30, 139-147

Greenfield, M., Kolterman, O., Olefsky, J. \& Reaven, G. M. (1980) Diabetologia 18, 441-446

Gregersen, G., Borsting, H., Theil, P. \& Servo, C. (1978) Acta Neurol. Scand. 58, 241-248

Gregersen, G., Bertelsen, B. \& Harbo, H. (1983) Acta Neurol. Scand. 67, 164-172

Grigorescu, F., Flier, J. S. \& Kahn, C. R. (1987) J. Clin. Endocrinol. Metab. 64, 549-554

Grunberger, G., Ryan, J. \& Gorden, P. (1982) Diabetes 31, 890-896

Grunberger, G., Zick, Y. \& Gordon, P. (1984) Science 223, 932-934

Guy, A. J., Alderson, D., Griffin, S. M. \& Farndon, J. (1987) Transplantation Proc., in the press

Haeckel, R. \& Haeckel, H. (1982) Diabetologia 7, 117-124

Hall, S., Braaten, J., McKendry, J., Bolton, T., Foster, D. \& Berman, M. (1979) Diabetes 28, 737-745

Halter, J. B., Graf, R. J. \& Porte, D. (1979) J. Clin. Endocrinol. Metab. 48, 946-954

Handelsman, D. J. \& Turtle, J. R. (1981) Diabetes 30, 459-464

Hansen, I., Firth, R., Haymond, M., Cryer, P. \& Rizza, R. (1986) Diabetes 35, 186-191

Harano, Y., Kashiwaga, A., Kojima, H., Suzuki, M., Hashimoto, T. \& Shigeta, Y. (1985) FEBS Lett. 188, 267-271

Heaton, D. A., Millward, B. A., Gray, P., Tun, Y., Hales, C. N., Pyke, D. A. \& Leslie, R. D. G. (1987) Br. Med. J. 294, 145-146

Hellman, B. (1986) Diabetes Metab. Rev. 2, 215-241

Henry, R. R., Wallace, P. \& Olefskey, J. M. (1986) Diabetes 35, 990-998

Herington, A. C., Corneli, H. J. \& Kuffer, A. D. (1983) Int. J. Biochem. 15, 1201-1210

Hers, H. G. \& Hue, L. (1983) Annu. Rev. Biochem. 52, 617-653

Hidaka, H., Nagulesparan, M., Klimes, I., Clark, R., Sasaki, H., Aronoff, S. L., Vasquez, B., Rubenstein, A. H. \& Unger, R. H. (1982) J. Clin. Endocrinol. Metab. 54, 217-222

Hissin, P. J., Foley, J. F., Wardzala, L. J., Karnicki, E., Simpson, I. A., Salans, L. B. \& Cushman, S. W. (1982) J. Clin. Invest. 70, 780-790

Hjollund, E., Pedersen, O., Richelsen, B., Beck-Nielsen, H. \& Sorensen, N. S. (1983) Metabolism 32, 1067-1075

Hjollund, E., Beck-Nielsen, H., Pedersen, O., Richelsen, B. \& Sorensen, N. S. (1985) Diabetic Med. 2, 468-473

Hjollund, E., Pedersen, O. \& Sorensen, N. S. (1987) Diabetes Care 10, 306-312

Hollenbeck, C. B., Chen, Y.-D. I., \& Reaven, G. M. (1984) Diabetes 33, 622-626

Honnor, R. C. \& Saggerson, E. D. (1980) Biochem. J. 188, 757-761

Houssay, B. A., Penhos, J. C. \& Urgoiti, E. (1957) Ann. N.Y. Acad. Sci. 71, 25-34 
Husband, D. J., Marshall, S. M., Walford, S., Hanning, I., Wright, P. D. \& Alberti, K. G. M. M. (1984) Diabetic Med. 2, 99-104

Jackson, R. A., Perry, G., Rogers, J. \& Pilkington, T. R. E. (1973) Diabetes 22, 751-761

Jackson, R. A., Roshania, R. D., Hawa, M. I., Sim, B. M. \& DiSilvo, L. (1986) J. Clin. Endocrinol. Metab. 63, 541-549

Jackson, R. A., Hawa, M. I., Jaspan, J. V., Sima, B. M., Disilvio, L., Featherbe, D. \& Kurtz, A. B. (1987a) Diabetes 36, 632-640

Jackson, R. A., Hamling, J. B., Sim, B. M., Hawa, M. I., Blix, P. M. \& Nabarro, J. D. N. (1987b) Metabolism 36, 144-150 Jacobsen, J. (1978) Diabetologia, 14, 113-119

Jaspan, J. B., Herold, K. \& Bartkus, C. (1985) Am. J. Med. 79, $25-37$

Jeffrey, J. \& Jornvall, H. (1983) Proc. Natl. Acad. Sci. U.S.A. 80, 901-905

Jimenez, J. T., Walford, S., Home, P. D., Hanning, I. \& Alberti, K. G. M. M. (1985) Diabetologia 28, 728-733

Johnston, D. G. \& Alberti, K. G. M. M. (1982) J. Clin. Endocrinol. Metab. 11, 329-361

Johnston, D. G., Gill, A., Ørskov, H., Batstone, G. F. \& Alberti, K. G. M. M. (1982) Metabolism 31, 312-317

Jones, I. R., Owens, D. R., Luzio, S., Hayes, T. M. \& Moody, A. J. (1987) Diabetologia, in the press

Judzewitsch, R. H., Jaspan, J., Polonsky, K. S. et al. (1983) N. Engl. J. Med. 308, 119-125

Kahn, B. B. \& Cushman, S. W. (1985) Diabetes Metab. Rev. 1, 203-227

Kahn, C. R. (1985) Annu. Rev. Med. 36, 429-451

Karnieli, E., Zarnowski, M. J., Hissin, P. J., Simpson, I. A., Salans, L. B. \& Cushman, S. W. (1981a) J. Biol. Chem. 256, 4772-4777

Karnieli, E., Hissin, P. J., Simpson, I. A., Salans, L. B. \& Cushman, S. W. (1981b) J. Clin. Invest. 68, 811-814

Kashiwagi, A. Verso, M. A., Andrews, J., Vasquez, B., Reaven, G. \& Foley, J. E. (1983) J. Clin. Invest. 72, 1246-1254

Katz, L. D., Glickman, M. D., Rapoport, S., Ferrannini, E. \& DeFronzo, R. A. (1983) Diabetes 32, 675-679

Katz, J. \& McGarry, J. (1984) J. Clin. Invest. 74, 1901-1909

Keller, U. (1986) Diabetologia 29, 71-77

Keller, U., Gerber, P. P. G. \& Stauffacher, W. (1984a) Am. J. Physiol. 247, E737-E739

Keller, U., Schnell, H., Girard, J. \& Stauffachner, W. (1984b) Diabetologia 26, 103-108

Kesaniemi, Y. A., Witzum, J. L. \& Steinbrecker, U. P. (1983) J. Clin. Invest. 71, 950-959

King, G. L., Goodman, D., Buzney, S., Moses, A. \& Kahn, R. C. (1985) J. Clin. Invest. 75, 1028-1036

Kissebah, A. H., Alfarsi, S., Evans, D. J. \& Adams, P. W. (1982) Diabetes 31, 217-225

Kissebah, A. H., Alfansi, S., Evans, D. J. \& Adams, P. W. (1987) Diabetes 31, 217-225

Koglin, L., Clarke, C., Ryder, S. \& Mullane, J. F. (1985) Diabetes, 34 (Suppl. 1), 202A

Kohn, R. R. \& Schnider, S. L. (1982) Diabetes 31 (Suppl. 3), 47-51

Kolterman, O., Prince, M. \& Olefsky, J. (1983) Am. J. Med. 74, 82A-101A

Kolterman, O. G., Gray, R. M. S., Shapiro, G., Scarlett, J. A., Griffin, J. \& Olefsky, J. M. (1984) Diabetes 33, 346-354

Komjati, M., Breitenecker, F., Bratusch-Marrain, P., Gampe, J., Vierhapper, H., Troch, I. \& Woldhouse, W. (1985) Endocrinology (Baltimore) 116, 978-986

Koorevaar, G. \& van Stekelenburg, G. J. (1976) Clin. Chim. Acta. 71, 173-183

Kosugi, K., Scofield, R. F., Chandramouli, V., Kumaran, K., Schumann, W. C. \& Landau, B. R. (1986a) J. Biol. Chem. 261, 3952-3957
Kosugi, K., Chandramouli, V., Kumaran, K., Schumann, W. C. \& Landau, B. R. (1986b) J. Biol. Chem. 261, 13179-13181

Kruszynska, Y. T., Petranyi, G., Home, P. D., Taylor, R. \& Alberti, K. G. M. M. (1986) Diabetologia 29, 699-705

Laker, M. E. \& Mayes, P. A. (1984) Biochim. Biophys. Acta 995, 427-430

Lardinois, C. K., Greenfield, M. S., Schwartz, H. C., Vreman, H. J. \& Reanen, G. M. (1984) Arch. Int. Med. 144, 345-347

Leahy, J. L., Bonner-Weir, S. \& Weir, G. (1984) Diabetes 33, 667-673

Lefebvre, P. (1966) Diabetologia 2, 130

Le Marchand-Brustel, Y., Gremeaux, T., Ballotti, R. \& Van Obberghen, E. (1985) Nature (London) 315, 676-679

Liljenquist, J. E., Bomboy, J. D., Lewis, S. B., Sinclair-Smith, B. C., Felts, P. W., Lacy, W. W., Crofford, C. B. \& Liddie, G. W. (1974) J. Clin. Invest. 53, 190-197

Liu, G., Coulston, A., Chen, Y.-D. I. \& Reaven, G. M. (1983) Metabolism 32, 754-756

Low, P. A., Tuck, R. R., Dyck, P. J., Schmelzer, J. D. \& Yao, J. K. (1985) Proc. Natl. Acad. Sci. U.S.A. 81, 6894-6898

Lonnroth, P., Blohme, G., Lager, I., Tisell, L. E. \& Smith, U. (1983) Diabetes Care 6, 586-590

Madsbad, S., Faber, O. K., Binder, C., Alberti, K. G. M. M. \& Lloyd, B. (1981) Acta Diabetologia 18, 115-121

MacGorman, L. R., Rizza, R. A. \& Gerich, J. E. (1981) J. Clin. Endocrinol. Metab. 83, 556-559

Marchand, E., Grigorescu, F., Buysschaert, M., De Meyts, P., Ketelslegers, J. M., Brems, H., Nathan, M. L. \& Lambert, A. E. (1985) Mol. Physiol. 4, 83-93

Marshall, A., Gingerich, R. L. \& Wright, P. H. (1970) Metabolism 19, 1046-1052

Marshall, S., Taylor, R., Home, P. D. \& Alberti, K. G. M. M. (1988) Acta Endocrinol., in the press

McGarry, J. D., Mannaerts, G. P. \& Foster, D. W. (1977) J. Clin. Invest. 60, 265-270

Meistas, M. T., Vlachokosta, F. V., Gleason, R. E., Arcangeli, M. \& Aoki, T. T. (1985) Diabetes 34, 960-963

Metcalfe, P., Johnston, D. G., Nosadini, R., Ørskov, H. \& Alberti, K. G. M. M. (1981) Diabetologia 20, 123-128

Metz, S. A., Halter, J. B. \& Robinson, R. P. (1979) J. Clin. Endocrinol. Metab. 48, 827-835

Metz, S. A. (1984) Prostaglandins 27, 147-158

Meyer, F., Ipaktchi, M. \& Clauser, H. (1967) Nature (London) 213, 203-204

Miles, J. N., Rizza, R. A., Haymond, M. W. \& Gerich, J. E. (1980) Diabetes 29, 926-930

Millward, B. A., Alviggi, L., Hoskins, P. J., Johnston, C., Heaton, D., Botazzo, G. F., Vergani, D., Leslie, R. D. G. \& Pyke, D. A. (1986) Br. Med. J. 292, 793-796

Moonsammy, G. I. \& Stewart, M. A. (1967) J. Neurochem. 14, 1187-1193

Muller, W. A., Falcona, G. R. \& Unger, R. H. (1973) Am. J. Med. 54, 52-57

Nankervis, A., Proietto, J., Aitken, P., Harewood, M. \& Alford, F. (1982) Diabetologia 23, 320-325

Nattrass, M., Todd, P. G., Hinks, L., Lloyd, B. \& Alberti, K. G.fM. M. (1977) Diabetologia 13, 145-152

Nattrass, M. (1982) Ph.D. Thesis, University of Southampton

Nattrass, M., Hinks, L., Smythe, P., Todd, P. G. \& Alberti, K. G. M. M. (1978) Diabete Metab. 4, 175-180

Nikkila, E. A. (1984) in Diabetes and Heart Disease (Jarrett, R. J., ed), pp. 133-167, Elsevier, Amsterdam

Nikkila, E. A., Huttunen, J. K. \& Ehnholm, C. (1977) Diabetes 26, 11-21

Nosadini, R., Noy, G. A., Nattrass, M., Alberti, K. G. M. M., Johnston, D. G., Home, P. D. \& Ørskov, H. (1982) Diabetologia 23, 220-228 
Nosadini, R., Avogaro, A., Trevisan, R., Valerio, A., Tessari, P., Duner, E., Teingo, A., Del Prato, S., De Kreutzenberg, S., Muggeo, M. \& Crepaldi, G. (1987) Diabetes Care 10, 62-67

Ontko, J. A. (1972) J. Biol. Chem. 247, 1788-1800

Osterby, R. (1975) Acta Med. Scand. Suppl. 574, 1-82

Osterby, R., Anderson, A. R. \& Gregersen, G. (1986) Diabetic Nephropathy 5, 10-11

Owen, O. E. \& Reichard, G. A. (1971) J. Clin. Invest. 50, 1536-1545

Owen, O. E., Trapp, V. E., Skutches, C. L., Mozzoli, M. A., Hoeldtko, R. D., Boden, G. \& Reichard, G. A. (1982) Diabetes 31, 242-248

Pagano, G., Tagliaferro, V., Carta, Q., Caselle, M. T., Bozzo, C., Vitelli, F., Trovati, M. \& Cocuzza, E. (1983) Diabetologia 24, 351-354

Patsch, W., Franz, S. \& Schonfield, G. (1983) J. Clin. Invest. 71, 1161-1174

Patsch, W., Gotto, A. M. \& Patsch, R. F. (1986) J. Biol. Chem. 261, 9603-9606

Pedersen, O. \& Hjollund, E. (1982) Diabetes 31, 706715

Pedersen, O., Hjollund, E. \& Sorensen, S. (1981) Metabolism 31, 884-895

Pehling, G., Tessari, P., Gerich, J., Haymond, M., Service, F. \& Rizza, R. (1984) J. Clin. Invest. 74, 995-991

Pernet, A., Trimble, E. R., Kuntschen, F., Assal, J.-Ph, Hahn, C. \& Renold, A. E. (1985) J. Clin. Endocrinol. Metab. 61, 247-251

Pfeifer, M. A., Halter, J. B. \& Porte, D., Jr. (1981) Am. J. Med. 70, 579-588

Pfeifer, M. A., Brunzell, J. D., Best, J. D., Judzewitsch, R. G., Pietri, A. O., Dunn, F. L., Grundy, S. M. \& Taskin, P. (1983) Diabetes 32, 75-81

Piatti, P., Monti, L. \& Alberti, K. G. M. M. (1987) Diabetologia, in the press (abstr.)

Pietri, A. O., Dunn, F. L., Grundy, S. M. \& Raskin, P. (1983) Diabetes 32, 75-81

Pirart, J. (1978) Diabetes Care 1, 252-263

Pittner, R. A., Bracken, P., Fears, R. \& Brindley, D. N. (1986) FEBS Lett. 202, 131-133

Polansky, K. S., Licinio-Paiscao, J., Given, B. D., Pugh, W., Rue, P., Galloway, J., Karrison, T. \& Frank, B. (1986) J. Clin. Invest. 77, 98-106

Prager, R., Schernthaner, G. \& Graf, H. (1986) Diabete Metab. 12, 346-350

Proietto, J., Nankervis, A., Aitken, P., Caruso, G. \& Alford, F. (1983) Diabetologia 25, 331-335

Radziuk, J., McDonald, T., Rubenstein, D. \& Dupre, J. (1978) Metab. Clin. Exp. 27, 657-669

Randle, P. J., Hales, C. N., Garland, P. B. \& Newsholme, E. A. (1963) Lancet i, 785-789

Raskin, P., Pietri, A. O., Unger, R. \& Shannon, W. A. (1983) N. Engl. J. Med. 309, 1546-1550

Reaven, G. M., Chen, Y.-D. I., Donner, C. C., Fraze, E. \& Hollenbeck, C. B. (1985) J. Clin. Endocrinol. Metab. 61, 32-36

Reichard, G. A., Skutches, C. L., Hoeldtke, R. D. \& Owen, O. E. (1986) Diabetes 35, 668-674

Revers, R. R., Fink, R., Griffin, J., Olefsky, J. M. \& Kolterman, O. G. (1984) J. Clin. Invest. 73, 664-672

Rizza, R. A., Cryer, P. E. \& Gerich, J. E. (1979a) J. Clin. Invest. 64, 62-71

Rizza, R., Verdonk, C., Miles, J., Servili, F. \& Gerich, J. $(1979 b)$ J. Clin. Invest. 63, 1119-1123

Rizza, R., Cryer, P. E., Haymond, M. \& Gerich, J. (1980) J. Clin. Invest. 65, 687-689

Rizza, R. A., Mandarino, L. \& Gerich, J. E. (1981) Diabetes 30, 990-995
Robertson, R. P. \& Chen, M. (1977) J. Clin. Invest. 60, 747-753

Robertson, R. P., Halter, J. B. \& Porte, D. (1976) J. Clin. Invest. 57, 791-795

Robinson, A. M. \& Williamson, D. H. (1980) Physiol. Rev. 60, 143-187

Robison, W. G., Jr., Kador, P. F. \& Kinoshita, J. H. (1983) Science 221, 1177-1179

Roth, R. A. \& Beaudoin, J. (1987) Diabetes 36, 123-126

Robison, W. G., Kador, P. F. \& Kinoshita, J. H. (1985) Diabetic Med. 2, 196-199

Rohrbach, D. H., Hassell, J. R., Kleinman, H. K. \& Martin, G. R. (1982) Diabetes 31, 185-188

Rorsman, P., Abrahamsson, H., Gylfe, E. \& Hellman, B. (1984) FEBS Lett. 170, 196-200

Rosenbloom, A. L., Silverstein, J. H., Riley, W. J. \& Maclaren, N. K. (1983) Diabetes Care 6, 370-373

Salhanick, A. I., Konowitz, P. \& Amatruda, J. M. (1983) Diabetes 32, 206-212

Saltiel, A. R., Fox, J. A., Sherline, P. \& Cuatrecasas, P. (1986) Science 233, 967-972

Salway, J. G., Whitehead, L., Finnegan, J. A., Karunanayaka, A., Barnett, D. \& Payne, R. B. (1978) Lancet ii, 12821284

Samad, A. H. B., TyWilling, T. S., Alberti, K. G. M. M. \& Taylor, R. (1988) Diabetes Care, in the press

Saito, K., Yaginuma, N. \& Takahashi, T. (1979) Tohoku J. Exp. Med. 129, 273-283

Scarlett, J. A., Gray, R. S., Griffin, J., Olefsky, J. M. \& Kolterman, O. G. (1982) Diabetes Care 5, 353-363

Scarlett, J. A., Kolterman, O. G., Ciaraldi, T. P., Kao, M. \& Olefsky, J. M. (1983) J. Clin. Endocrinol. Metab. 56, 1195-1201

Schade, D. S. \& Eaton, R. P. (1976) Diabetes 25, 978-983

Schade, D. S. \& Eaton, R. P. (1978) Diabetologia 15, 433439

Schade, D. S., Eaton, P. R. \& Peake, G. T. (1978) Diabetes 27, 916-924

Scheen, A. J., Lefebvre, P. J. \& Luyckx, A. S. (1984) Eur. J. Clin. Pharmacol. 26, 471-474

Selby, P. L., Bartlett, K., Sherratt, H. S. A. \& Alberti, K. G. M. M. (1987) Diabetologia, in the press

Sener, A. \& Malaisse, W. J. (1984) Experimentia 40, 1026-1035

Sener, A., Kawasu, S., Hutton, J. C., Boschuro, A. C., Devis, G., Somers, G., Hirchuctz, A. \& Malaisse, W. J. (1978) Biochem. J. 176, 217-232

Service, F. J., Rizza, R. A., Daube, J. R., O'Brien, P. C. \& Dyck, P. J. (1985) Diabetologia 28, 722-727

Sheppard, M. C., Burrin, J., Alberti, K. G. M. M. \& Nattrass, M. (1983) Diabetologia 24, 333-335

Simpson, I. A. \& Hedo, J. A. (1984) Science 223, 1301-1304

Singh, B. M., Palma, M. A. \& Nattrass, M. (1987) Diabetes 36, 740-748

Sinha, M. K., Pories, W. J., Flickinger, E. G., Meelheim, O. \& Caro, J. F. (1987) Diabetes 36, 620-625

Spencer, K. M., Tarn, A., Dean, B. M., Lister, J. \& Botazzo, G. F. (1984) Lancet i, 764-766

Srikanta, S., Ganda, O. P., Jackson, R. A. et al. (1983) Ann. Intern. Med. 99, 320-326

Srivastava, S. K., Ansari, N. H., Hair, G. A. \& Das, B. (1984) Biochim. Biophys. Acta 800, 220-227

Stark, A., Imamura, T. \& Unger, R. H. (1987) J. Clin. Invest. 79, 20-24

Stevenson, R. W., Parsons, J. A. \& Alberti, K. G. M. M (1983a) Am. J. Physiol. 244, E190-E195

Stevenson, R. W., Ørskov, H., Parsons, J. A. \& Alberti, K. G. M. M. (1983b) Am. J. Physiol. 245, E200-E208

Stiller, C. R., Dupre, J., Gent, M. et al. (1984) Science 223, 1362-1367 
Stone, D. B. \& Brown, J. D. (1967) Excerpta Med. 202-207

Stout, R. (1979) Diabetologia 16, 141-150

Summerfield, J. A., Vergalla, J. \& Jones, E. A. (1982) J. Clin. Invest. 69, 1337-1347

Swislocki, A. L. M., Donner, C. C., Fraze, E., Chen, Y.-D. I. \& Reaven, G. M. (1987) J. Clin. Endocrinol. Metab. 64, 778-782

Tarn, A. C., Smith, C. P., Spencer, K. M., Botazzo, G. F. \& Gale, E. A. M. (1987) Br. Med. J. 294, 342-345

Taskinen, M. R. \& Nikkila, E. A. (1979) Diabetologia 17, 351-356

Taskinen, M. R., Nikkila, E. A., Kuusi, T. \& Haino, K. (1982) Diabetologia 22, 46-50

Taskinen, M. R., Beltz, W. F., Harper, I., Fields, R. M., Schonfield, G., Grundy, S. M. \& Howard, B. V. (1986) Diabetes 35, 1268-1277

Tchobroutsky, G. (1978) Diabetologia 15, 143-152

Taylor, R. \& Argyraki, M. (1987) Diabetologia, in the press

Tomlinson, D. R. \& Mayer, J. H. (1984) J. Autonom. Pharmacol. 4, 59-72

Tomlinson, D. R., Townsend, J. \& Frettin, P. (1985) Diabetes 34, 970-972

Topping, D. L. \& Mayes, P. A. (1982) Biochem. J. 204, 433-439

Turner, R. C., McCarthy, S. T., Holman, R. R. \& Harris, E. (1976) Br. Med. J. 1, 1252-1254

Tutwiler, G. F., Kirsch, T. H., Mohrbacker, R. H. \& Ho, W. (1978) Metabolism 27, 1539-1556

Ullrich, A., Bell, J. R., Chen, E. Y., Herrera, R., Petruzzelli, L. M., Dull, T. J., Gray, A., Coussens, L., Lias, Y.-C., Tsubokawa, M., Masson, A., Seeburg, P. H., Grunfeld, C., Rosen, O. M. \& Ramachandran, J. (1985) Nature (London) 313, 756-761

Uy, R. \& Wold, E. F. (1977) Science 198, 890-896

Vigneri, R., Ezino, V., Wong, K. Y. \& Goldfine, I. D. (1982) J. Clin. Endocrinol. Metab. 54, 95-100
Vranic, M. \& Wrenshall, G. A. (1968) Can. J. Physiol. Pharmacol. 46, 383-397

Wahren, J., Felig, P., Cerasi, E. \& Luft, R. (1972) J. Clin. Invest. 51, 1870-1878

Waldhausl, W., Bratusch-Marrain, P., Gasic, S., Korn, A. \& Nowotny, P. (1982) Diabetologia 23, 6-15

Ward, D. J., Baker, R. W. P. \& Davis, B. H. (1972) Diabetes 21, 1173-1178

Ward, W. K., Halter, J. B., Best, J. D., Beard, J. C. \& Porte, D., Jr. (1983) Diabetes 32, 943-947

Ward, W. K., Bolgiano, D. C., McKnight, B., Halter, J. B. \& Porte, D., Jr. (1984) J. Clin. Invest. 74, 1318-1328

Ward, G., Harrison, L. C., Proietto, J., Aitken, P. \& Nankervis, A. (1985) Diabetes 34, 241-245

Whikehart, D. R. \& Soppet, D. R. (1981) Curr. Eye Res. 1, 451-455

White, M. F., Maron, R. \& Kahn, C. R. (1985) Nature (London) 318, 183-186

Willars, G. P., Calcutt, N. A. \& Tomlinson, D. R. (1987) Diabetologia 30, 239-243

Yalow, R. A., Black, H., Vilason, M. \& Berson, S. A. (1960) Diabetes 9, 356-359

Yamauchi, K. \& Hashizume, K. (1986) Endocrinology (Baltimore) 119, 218-223

Yki-Jarvinen, H., Taskinen, K.-R., Kiviluoto, T., Hilden, H., Helve, E., Koivisto, V. A. \& Nikkila, E. A. (1984) J. Clin. Endocrinol. Metab. 59, 1183-1192

Yki-Jarvinen, H., DeFronzo, R. A. \& Koivisto, V. A. (1984) Diabetes Care 7, 520-527

Young, R. J., Ewing, D. J. \& Clarke, B. J. (1983) Diabetes 32 938-942

Zawadzki, J. K., Bogardus, C. \& Foley, J. E. (1987) Diabetes 36, 227-236

Zawalich, W. S., Dye, E. S., Rogenstad, R. \& Matschinsky, F. M. (1978) Endocrinology (Baltimore) 103, 20272034 